Prepared in cooperation with the Tampa Bay Estuary Program

\title{
Tampa Bay Ocean and Coastal Acidification Monitoring Quality Assurance Project Plan
}

By Kimberly K. Yates, Christopher S. Moore, Nathan H. Goldstein, and Edward T. Sherwood

Open-File Report 2019-1003

U.S. Department of the Interior

U.S. Geological Survey 


\title{
U.S. Department of the Interior DAVID BERNHARDT, Acting Secretary
}

\author{
U.S. Geological Survey \\ James F. Reilly II, Director
}

U.S. Geological Survey, Reston, Virginia: 2019

For more information on the USGS-the Federal source for science about the Earth, its natural and living resources, natural hazards, and the environment-visit https://www.usgs.gov/ or call 1-888-ASK-USGS (1-888-275-8747).

For an overview of USGS information products, including maps, imagery, and publications, visit https://store.usgs.gov.

Any use of trade, firm, or product names is for descriptive purposes only and does not imply endorsement by the U.S. Government.

Although this information product, for the most part, is in the public domain, it also may contain copyrighted materials as noted in the text. Permission to reproduce copyrighted items must be secured from the copyright owner.

Suggested citation:

Yates, K.K., Moore, C.S., Goldstein, N.H., and Sherwood, E.T., 2019, Tampa Bay Ocean and Coastal Acidification Monitoring Quality Assurance Project Plan: U.S. Geological Survey Open-File Report 2019-1003, 35 p., https://doi.org/10.3133/ofr20191003.

ISSN 2331-1258 (online) 


\section{Acknowledgments}

The Tampa Bay Ocean and Coastal Acidification Monitoring project was developed and refined with help from several contributors. We thank Ryan Moyer, Amanda Chappel, Christina Powell, and loana Bociu of the Florida Fish and Wildlife Conservation Commission Fish and Wildlife Research Institute; Dave Tomasko of Environmental Science Associates; and Nathan Smiley and Legna Torres-Garcia of the U.S. Geological Survey (USGS) for their assistance with pilot experiments to guide development of the monitoring approach. Mark Luther, Robert Weisburg, Jason Law, Randy Russell, and Jeff Donovan of the University of South Florida provided technical guidance for and access to the Tampa Bay Physical Oceanographic Real-Time System and the Coastal Ocean and Monitoring Prediction System for deployment of instrumentation. Lance Thornton of the USGS assisted with design and construction of mounts for the Ocean Carbon Systems. Mitch Lemon, Nathan Goldstein, and Joseph Vargas of the USGS assisted with laboratory and field validation of the Ocean Carbon Systems. This work was funded by the U.S. Environmental Protection Agency National Estuary Program, the Tampa Bay Estuary Program, the Tampa Bay Environmental Restoration Fund, and the USGS Coastal and Marine Geology Program. 


\section{Contents}

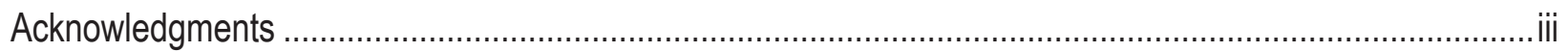

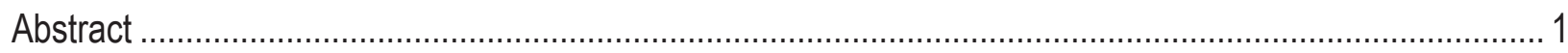

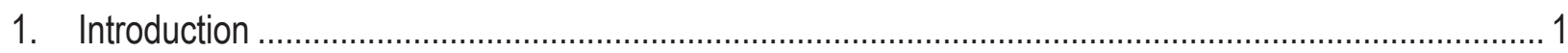

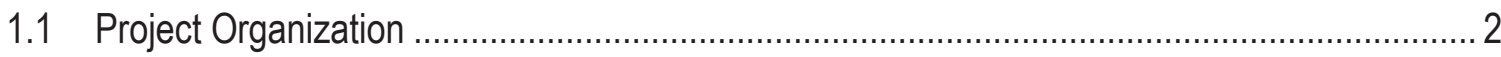

1.1.1 Tampa Bay Estuary Program ............................................................................ 3

1.1.2 U.S. Geological Survey St. Petersburg Coastal and Marine Science Center ................... 3

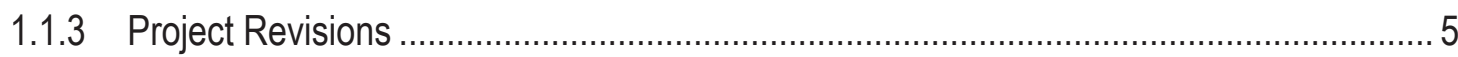

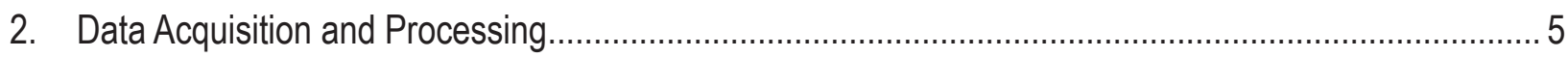

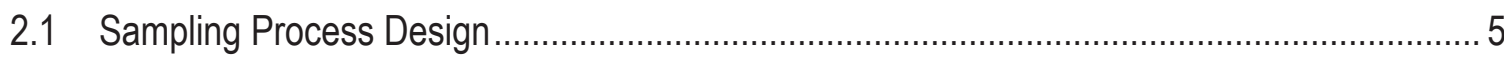

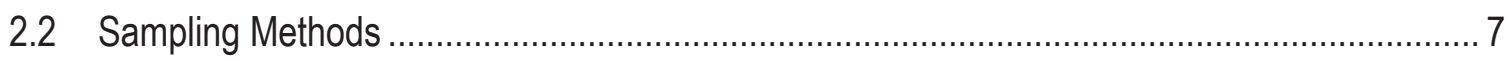

2.2.1 Automated Sampling Procedures .................................................................... 7

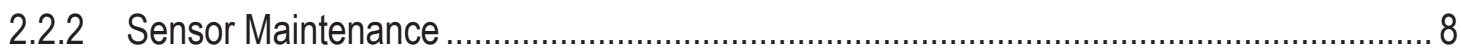

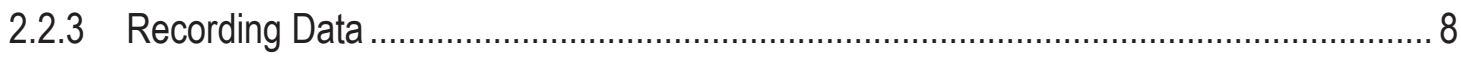

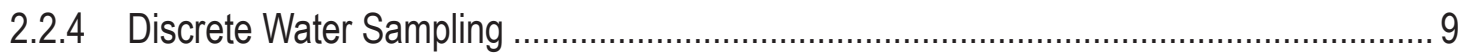

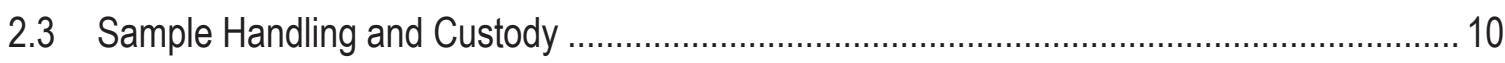

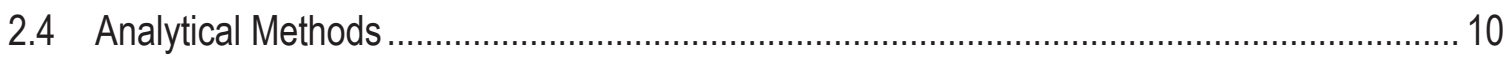

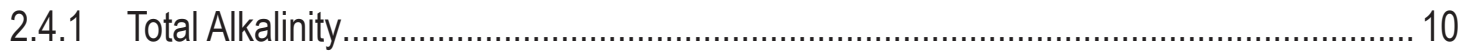

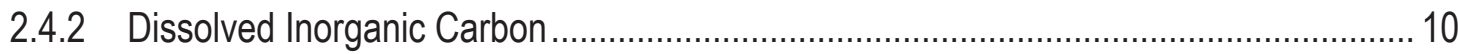

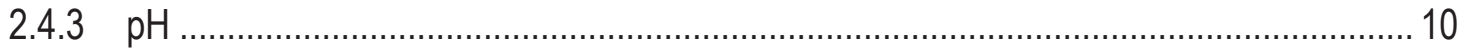

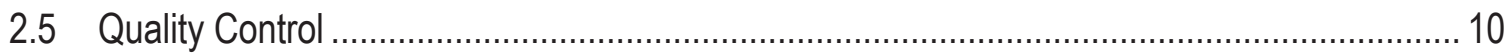

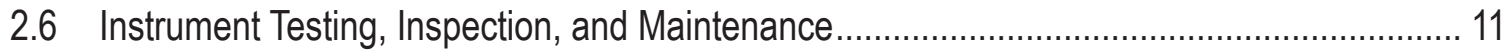

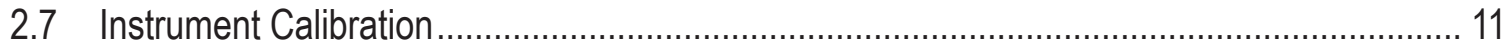

2.8 Inspection of Supplies and Consumables ....................................................................... 11

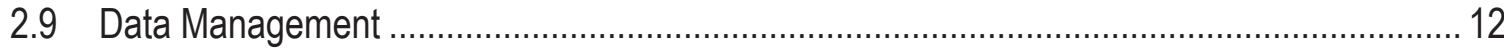

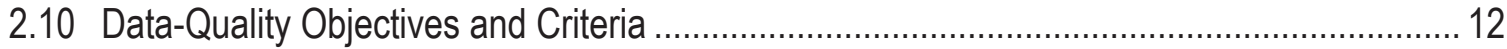

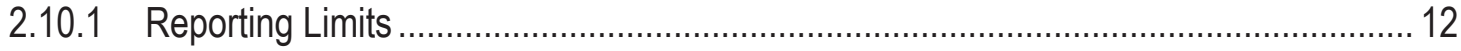

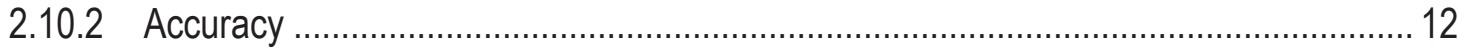

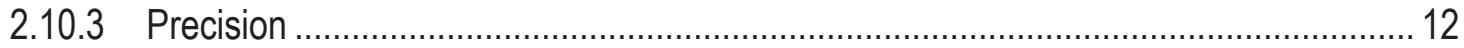

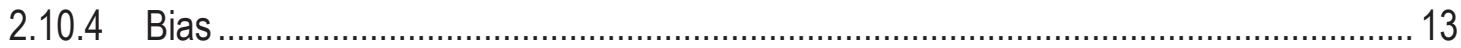

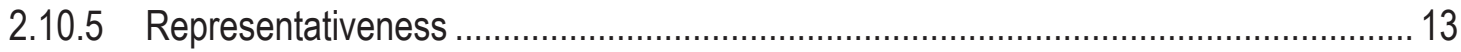

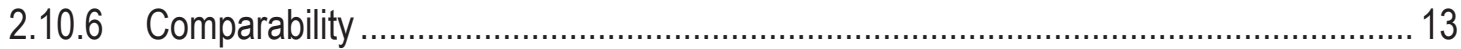

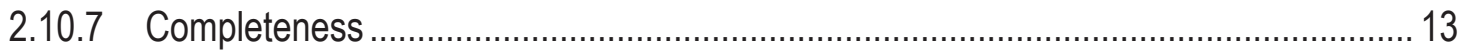


2.11 Personnel Training .................................................................................................... 13

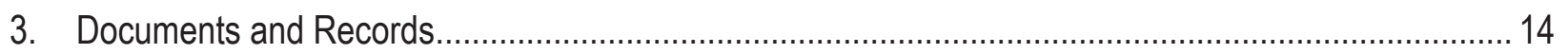

4. Assessment, Oversight, and Reports to Management.................................................................. 15

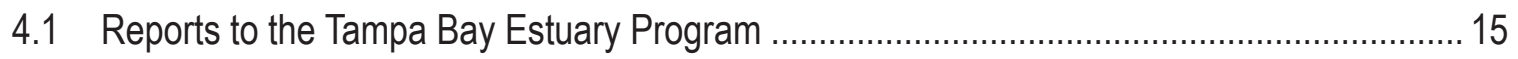

4.2 Reports from the Carbon Analytical Laboratory ........................................................... 15

4.3 Reports to the U.S. Environmental Protection Agency ................................................. 15

5. Data Review, Verification, and Validation .................................................................................... 16

5.1 Data Validation and Verification Methods …………….................................................... 17

5.2 Reconciliation with User Requirements ........................................................................... 17

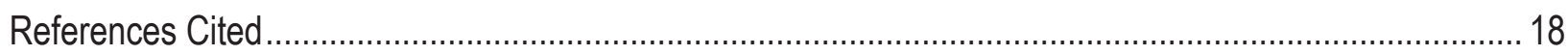

Appendix 1. Sensor Specifications ................................................................................................. 19

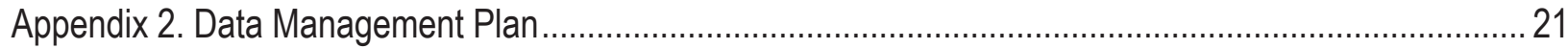

Appendix 3. Water Sampling Protocol for Total Alkalinity, Dissolved Inorganic Carbon, and pH Analyses .. 22

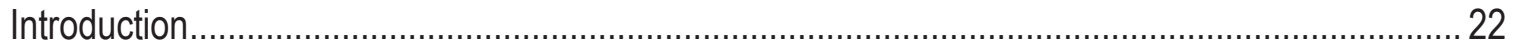

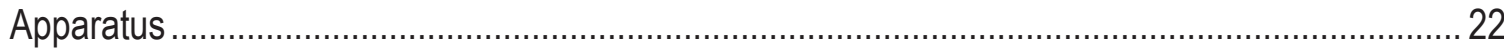

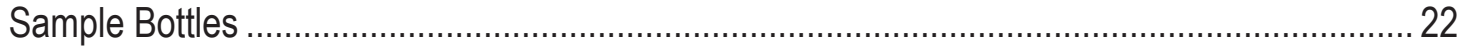

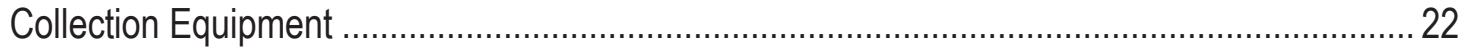

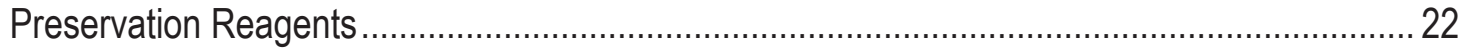

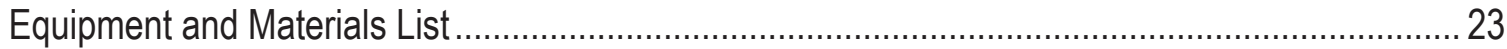

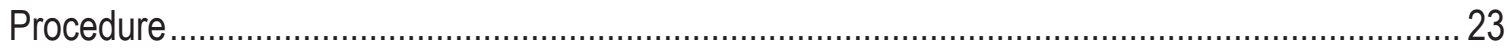

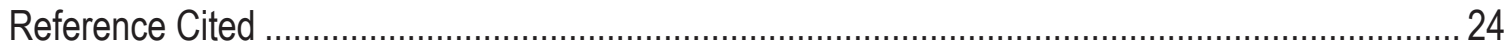

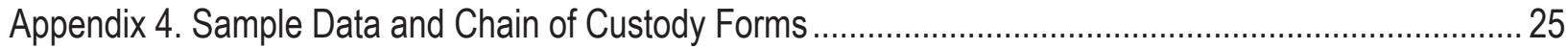

Appendix 5. Standard Operating Procedures for Chemical Analyses ........................................................ 27

Spectrophotometric Determination of Total Alkalinity ……….................................................. 27

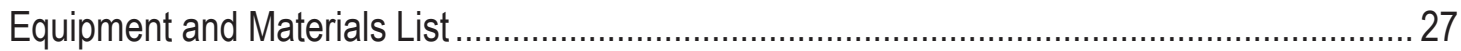

Preparation of Hydrochloric Acid ................................................................................... 28

Running Samples or Certified Reference Materials ............................................................... 28

Coulometric Determination of Total Dissolved Inorganic Carbon in Seawater .............................. 30

Equipment and Materials List ......................................................................................... 30

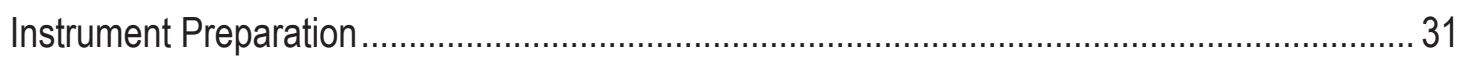

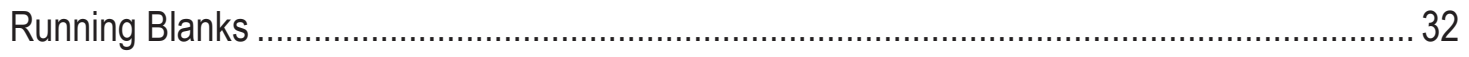

Running Samples or Certified Reference Materials ................................................................. 32 


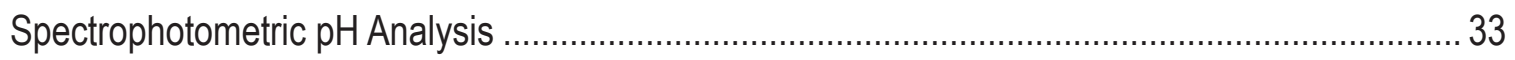

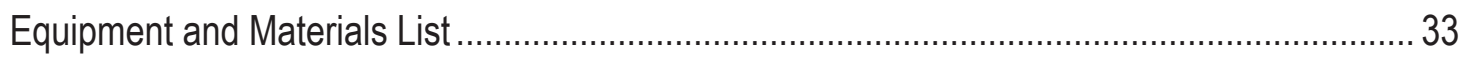

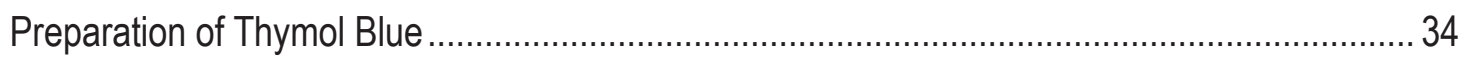

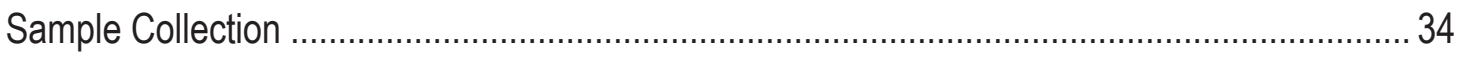

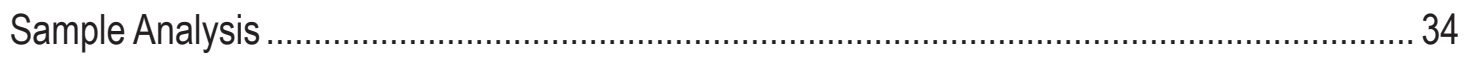

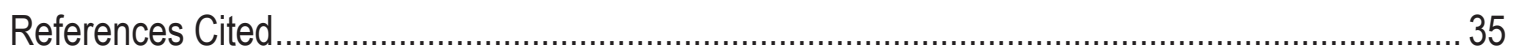

\section{Figures}

1. Organization chart indicating lines of supervision and communication for the Tampa Bay Ocean and Coastal Acidification Monitoring project...............................................................................

2. First generation Ocean Carbon System housed inside of a trawl resistant mount on the seafloor; the OCS system used for this project was constructed in a similar manner using the most recent models of similar sensors

\section{Tables}

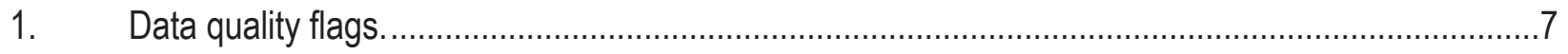

2. Performance specifications indicating range of measurement for field instruments. .....................13

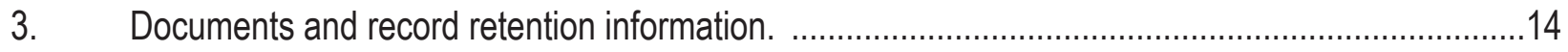

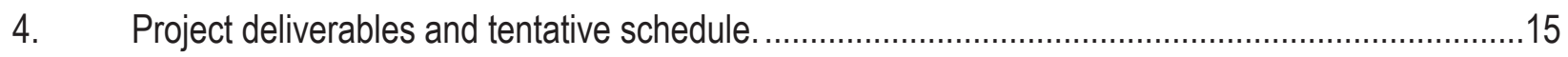

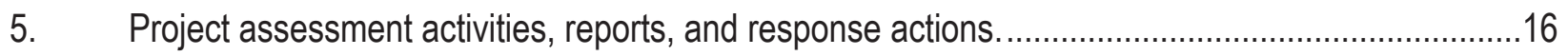

1.1. Specifications for the Sea-bird Scientific SeapHOx sensor..........................................................19

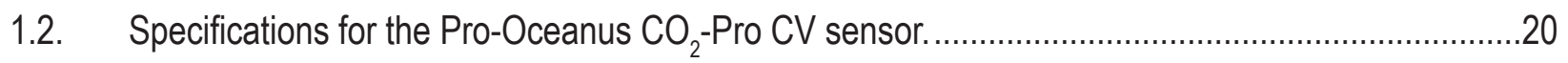

1.3. Specifications for the WetLabs ECO-PAR sensor.

1.4. Specifications for the Sea-bird Scientific STOR-X submersible data logger. ..................................20 


\section{Conversion Factors}

\begin{tabular}{|c|c|c|}
\hline Multiply & By & To obtain \\
\hline \multicolumn{3}{|c|}{ Length } \\
\hline nanometer (nm) & $3.910^{-8}$ & inch (in.) \\
\hline centimeter (cm) & 0.3937 & inch (in.) \\
\hline millimeter (mm) & 0.03937 & inch (in.) \\
\hline meter $(\mathrm{m})$ & 3.281 & foot $(\mathrm{ft})$ \\
\hline \multicolumn{3}{|c|}{ Volume } \\
\hline liter (L) & 33.81402 & ounce, fluid (fl. oz) \\
\hline liter $(\mathrm{L})$ & 2.113 & pint $(p t)$ \\
\hline liter (L) & 1.057 & quart (qt) \\
\hline liter (L) & 0.2642 & gallon (gal) \\
\hline liter $(\mathrm{L})$ & 61.02 & cubic inch $\left(\mathrm{in}^{3}\right)$ \\
\hline \multicolumn{3}{|c|}{ Mass } \\
\hline gram (g) & 0.03527 & ounce, avoirdupois (oz) \\
\hline kilogram (kg) & 2.205 & pound avoirdupois (lb) \\
\hline milligram (mg) & 0.00003527 & ounce, avoirdupois (oz) \\
\hline
\end{tabular}

Temperature in degrees Celsius $\left({ }^{\circ} \mathrm{C}\right)$ may be converted to degrees Fahrenheit $\left({ }^{\circ} \mathrm{F}\right)$ as ${ }^{\circ} \mathrm{F}=\left(1.8 \times{ }^{\circ} \mathrm{C}\right)+32$.

\section{Datum}

Horizontal coordinate information is referenced to the World Geodetic System of 1984 (WGS 84).

\section{Abbreviations}

$\begin{array}{ll}\text { A } & \text { absorbance } \\ \mathrm{BCP} & \text { bromocresol purple } \\ \mathrm{BOD} & \text { biological oxygen demand } \\ { }^{\circ} \mathrm{C} & \text { degree Celsius } \\ \mathrm{CAL} & \text { Carbon Analytical Laboratory } \\ \mathrm{Cm} & \text { centimeter } \\ \mathrm{CO}_{2} & \text { carbon dioxide } \\ \mathrm{COMPS}^{-} & \text {Coastal Ocean Monitoring and Prediction System } \\ \mathrm{CRM} & \text { certified reference material } \\ \mathrm{CTD} & \text { conductivity, temperature, and depth } \\ \mathrm{DIC} & \text { dissolved inorganic carbon } \\ \mathrm{DO} & \text { dissolved oxygen } \\ \mathrm{EPA} & \text { U.S. Environmental Protection Agency } \\ \mathrm{EST} & \text { Eastern Standard Time } \\ \mathrm{g} & \text { gram } \\ \mathrm{GOM} & \text { Gulf of Mexico } \\ \mathrm{HCl} & \text { hydrochloric acid } \\ \mathrm{HgCl} & \text { mercuric chloride } \\ \mathrm{Hz} & \text { hertz }\end{array}$




\begin{tabular}{|c|c|}
\hline in & inch \\
\hline $\mathrm{kg}$ & kilogram \\
\hline $\mathrm{m}$ & meter \\
\hline $\mathrm{mg}$ & milligram \\
\hline $\mathrm{mg} / \mathrm{L}$ & milligram per liter \\
\hline $\mathrm{mm}$ & millimeter \\
\hline $\mathrm{mM}$ & millimolar \\
\hline $\mathrm{mL}$ & milliliter \\
\hline $\mathrm{mS}$ & millisiemens \\
\hline $\mathrm{mS} / \mathrm{cm}$ & millisiemens per centimeter \\
\hline$N$ & normal \\
\hline $\mathrm{N}_{2}$ & nitrogen \\
\hline $\mathrm{NaOH}$ & sodium hydroxide \\
\hline $\mathrm{nm}$ & nanometer \\
\hline OCS & Ocean Carbon System \\
\hline PAR & photosynthetically active radiation \\
\hline $\mathrm{pCO}_{2}$ & partial pressure of carbon dioxide \\
\hline $\mathrm{pH}_{\mathrm{T}}$ & $\mathrm{pH}$ on the total scale \\
\hline $\mathrm{PI}$ & primary investigator \\
\hline PORTS & Physical Oceanographic Real-Time System \\
\hline ppm & part per million \\
\hline psi & pound per square inch \\
\hline QA/QC & Quality Assurance/Quality Control \\
\hline QAPP & Quality Assurance Project Plan \\
\hline S & second \\
\hline S & siemens \\
\hline $\mathrm{S} / \mathrm{m}$ & siemens per meter \\
\hline SOP & standard operating procedure \\
\hline SPCMSC & St. Petersburg Coastal and Marine Science Center \\
\hline TA & total alkalinity \\
\hline TBEP & Tampa Bay Estuary Program \\
\hline USGS & U.S. Geological Survey \\
\hline VDC & volt direct current \\
\hline$\mu a t m$ & microatmosphere \\
\hline$\mu g$ & microgram \\
\hline$\mu \mathrm{L}$ & microliter \\
\hline$\mu \mathrm{m}$ & micrometer \\
\hline$\mu M$ & micromolar \\
\hline$\mu \mathrm{mol} / \mathrm{kg}$ & micromole per kilogram \\
\hline
\end{tabular}




\title{
Tampa Bay Ocean and Coastal Acidification Monitoring Quality Assurance Project Plan
}

\author{
By Kimberly K. Yates, ${ }^{1}$ Christopher S. Moore, ${ }^{1}$ Nathan H. Goldstein, ${ }^{1}$ and Edward T. Sherwood ${ }^{2}$
}

\begin{abstract}
Coastal acidification caused by eutrophication, freshwater inflow, and upwelling is already affecting many estuaries worldwide and can be exacerbated by ocean acidification that is caused by increasing carbon dioxide in the atmosphere. Effective management, mitigation, and (or) adaptation to the effects of coastal and ocean acidification require careful monitoring of the resulting changes in seawater chemistry. Local, regional, and national agencies and institutions organizing acidification-monitoring and research efforts work toward standardizing data collection and reporting protocols so that data can be shared and compared across regions and synthesized into national assessments. This document describes a Quality Assurance Project Plan for the collection and reporting of seawater chemical and physical data using standardized methods and published best practices relevant for monitoring coastal and ocean acidification. The plan specifically addresses procedures for a joint partnership, the Tampa Bay Ocean and Coastal Acidification Monitoring project, conducted by the U.S. Geological Survey, the U.S. Environmental Protection Agency, and the Tampa Bay Estuary Program in the Tampa Bay estuary, Florida. The plan describes recommended procedures for project organization, sampling process design and methods, data-quality objectives and criteria, data validation and management procedures, and project deliverables.
\end{abstract}

\section{Introduction}

Ocean acidification is the decrease in seawater $\mathrm{pH}$ caused by the uptake of atmospheric carbon dioxide $\left(\mathrm{CO}_{2}\right)$ in the coastal and open ocean. Atmospheric $\mathrm{CO}_{2}$ concentrations have been increasing steadily since the beginning of the Industrial Revolution. $\mathrm{As}_{2} \mathrm{CO}_{2}$ dissolves into the ocean, carbonic acid is formed, leading to an increase in hydrogen-ion concentration, a decline in $\mathrm{pH}$, and a decrease in carbonate-ion concentration. Coastal acidification, caused by local and regional effects from eutrophication, upwelling, and freshwater flow into coastal systems, also increases the partial pressure of $\mathrm{CO}_{2}\left(\mathrm{pCO}_{2}\right)$ in seawater and decreases $\mathrm{pH}$ and carbonate-ion concentration. Changing the chemistry of the ocean has many consequences for marine organisms. Examples of organisms that could be or have been negatively affected by coastal and ocean acidification are oysters, shrimp, coral, sea urchins, some plankton species, and even fish species. For many marine organisms, an environment with decreasing $\mathrm{pH}$ hinders the production and maintenance of carbonate shells/skeletons or causes developmental delays. The decline of these organisms can have many cascading effects, such as changing marine food-web structures, decreasing shellfishery production, decreasing coral reef production, and destabilizing seafloor structure.

\footnotetext{
${ }^{1}$ U.S. Geological Survey

${ }^{2}$ Tampa Bay Estuary Program
} 
Many estuaries in the southeast region of the United States are experiencing a broad decline in both $\mathrm{pH}$ and alkalinity (acidification). Long-term water-quality monitoring data from the Environmental Protection Commission of Hillsborough County, Florida (http:/www.epchc.org/divisions/ water-management/water-monitoring-maps-and-data) indicate that daytime values of seawater $\mathrm{pH}$ in Tampa Bay decreased from approximately 1970 to the early 1980s when the rate of seagrass habitat loss was at its peak. However, daytime $\mathrm{pH}$ values have steadily risen in Tampa Bay since the early 1980s when local management strategies improved water quality, and seagrass beds have continued to recover since that time (Sherwood and others, 2016). Seagrasses are projected to benefit from elevated atmospheric $\mathrm{pCO}_{2}$ (Kleypas and Yates, 2009), are capable of increasing seawater $\mathrm{pH}$ and carbonate mineral saturation states through photosynthesis (Yates and others, 2016), and may help provide protection to organisms living in close association with seagrass beds (Semesi and others, 2009; Anthony and others, 2011; Manzello and others, 2012; Hendriks and others, 2014).

We hypothesize that the recovery of seagrass in Tampa Bay has helped buffer against the chemical effects of coastal and ocean acidification, may confer some resiliency to organisms that are particularly sensitive to acidification (such as shellfish and other economically important marine species), and may serve as an important regional coastal and ocean acidification refuge. Additionally, dissolution of carbonate sediments may also provide a buffering mechanism for seawater pH (Kleypas and Yates, 2009). Tampa Bay is characterized by a natural gradient in sediment composition; upper portions of the bay are dominated by siliciclastic sediments, and lower portions of the bay are dominated by carbonate sediments (Brooks and Doyle, 1998). This mineralogical gradient in Tampa Bay provides a unique opportunity to examine the role of carbonate sediments in the acidification process.

To study the evolving $\mathrm{pH}$ conditions in Tampa Bay relative to the near-coastal Gulf of Mexico (GOM) environment, the Tampa Bay Ocean and Coastal Acidification Monitoring project examines high-resolution temporal changes in carbon-system parameters $\left(\mathrm{pH}\right.$ and $\left.\mathrm{pCO}_{2}\right)$, productivity (dissolved oxygen), light climate (photosynthetically active radiation [PAR]), and physical water quality (conductivity, temperature, and depth) using customized, in situ sensor packages. The sensor packages include a Sea-bird Scientific STOR-X data logger integrated with a Sea-bird Scientific SeapHOx sensor kit, a Pro-Oceanus $\mathrm{CO}_{2}$-Pro CV sensor, and Wetlabs ECO-PAR sensors. The integrated sensor packages are deployed at appropriate Tampa Bay Physical Oceanographic Real-Time System (PORTS) and Coastal Ocean Monitoring and Prediction System (COMPS) sites located in lower-middle Tampa Bay and near-coastal waters in the GOM. The high-temporal-resolution data from the sensors allow us to examine both the short-term (daily to monthly) variations and long-term (interannual) changes in water carbonate chemistry in the Tampa Bay estuary and to contrast these variations with eastern GOM near-coastal waters.

This document provides a detailed Quality Assurance Project Plan (QAPP) for ocean and coastal acidification monitoring in Tampa Bay. The QAPP describes recommended procedures for project organization, sampling process design and methods, data-quality objectives and criteria, data validation and management procedures, and project deliverables.

\subsection{Project Organization}

The primary responsibilities for the project are performed as a partnership between the U.S. Geological Survey (USGS) and the Tampa Bay Estuary Program (TBEP). The following agency representatives carry out major responsibilities for the project's activities. The project communication and supervision structures are as indicated in figure 1. 


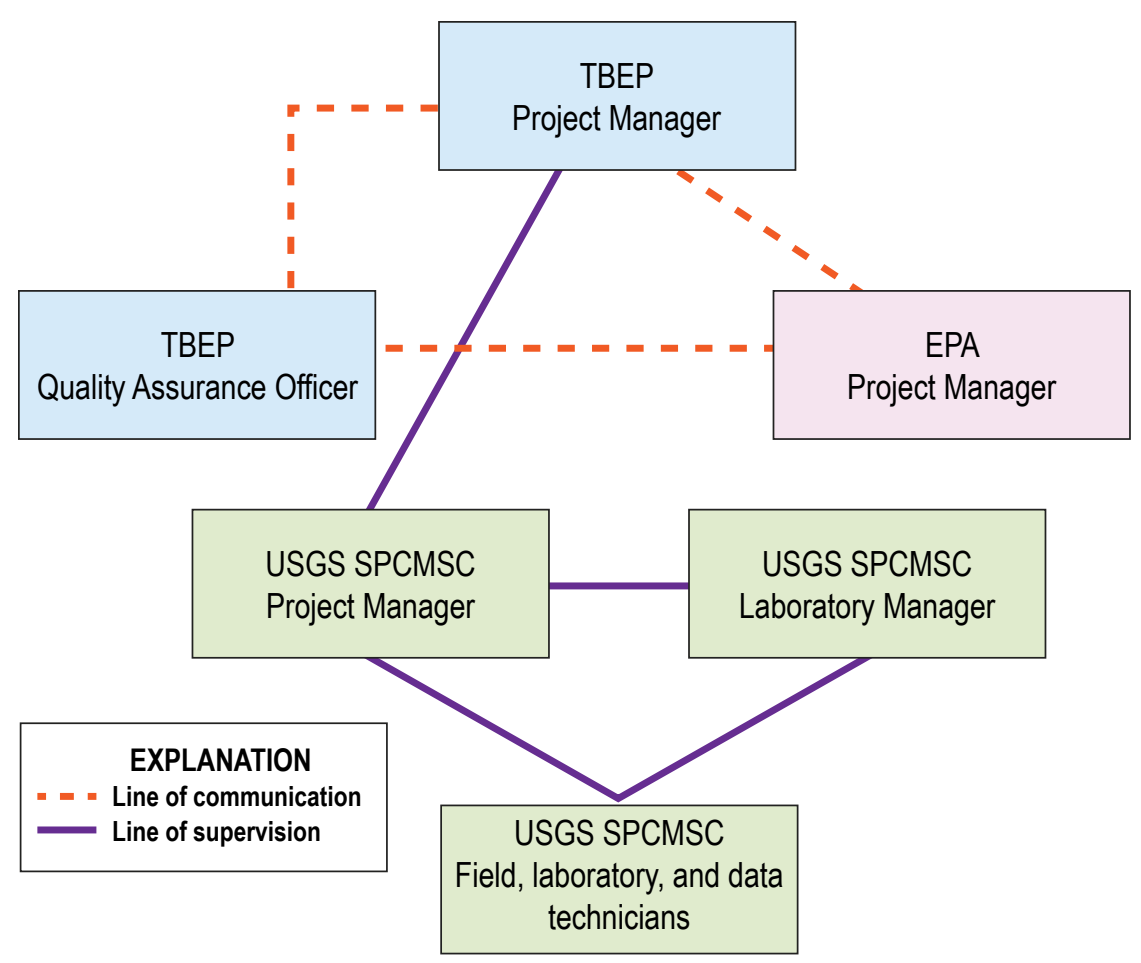

Figure 1. Organization chart indicating lines of supervision and communication for the Tampa Bay Ocean and Coastal Acidification Monitoring project. EPA, U.S. Environmental Protection Agency; SPCMSC, St. Petersburg Coastal and Marine Science Center; TBEP, Tampa Bay Estuary Program; USGS, U.S. Geological Survey.

\subsubsection{Tampa Bay Estuary Program}

The TBEP Project Manager is responsible for TBEP contract management and provides a point of contact between the TBEP and the USGS to fulfill the project goals. The TBEP Project Manager is also responsible for tracking deliverables and project progress and accurate, timely submission of project deliverables to the TBEP.

The TBEP Quality Assurance Officer is responsible for reviewing and approving the QAPP and any subsequent QAPP revisions. The Quality Assurance Officer works closely with the TBEP Project Manager to review QAPPs and implement the TBEP Quality Management Plan. The Quality Assurance Officer conducts monitoring-system and quality-system audits and coordinates corrective actions, if necessary, with the TBEP and program staff. Maintenance of quality-assurance (QA) records considered central to the project and submission of all QA reports are also responsibilities of the Quality Assurance Officer. The Project Manager and Quality Assurance Officer provide progress updates to the U.S. Environmental Protection Agency (EPA) Project Manager.

\subsubsection{U.S. Geological Survey St. Petersburg Coastal and Marine Science Center}

The USGS St. Petersburg Coastal and Marine Science Center (SPCMSC) Project Manager is responsible for ensuring that tasks and other requirements in the project contract are executed on time and in accordance with the quality-assurance/quality-control (QA/QC) requirements as defined by the project contract and the QAPP, participating in project work, submitting 
accurate and timely deliverables to the TBEP Project Manager, and coordinating attendance at conference calls, trainings, meetings, and related project activities with the TBEP. The USGS SPCMSC Project Manager is also responsible for verifying that the QAPP is distributed and followed by the USGS SPCMSC Carbon Analytical Laboratory (CAL) personnel and that the project is producing data of known and acceptable quality. Other duties of the USGS SPCMSC Project Manager include the following:

- Ensuring adequate training for CAL personnel and supervision of all activities involved in generating analytical data, taking corrective actions, and facilitating internal audits.

- Coordinating development and implementation of the CAL's QA program; writing and maintaining QAPPs; maintaining records of QAPP distribution, including appendixes and amendments, and monitoring their implementation; and maintaining written records of sub-tier commitment to requirements specified in this QAPP.

- Identifying, receiving, and maintaining project QA records.

- Coordinating with the TBEP to resolve QA-related issues

- Notifying the TBEP Project Manager of circumstances that may adversely affect the quality of data.

- Validating data prior to submission to the TBEP.

- Coordinating the research and review of technical QA material and data related to design of water-quality monitoring systems and analytical techniques.

- Conducting laboratory inspections, including developing, facilitating, and conducting monitoring-system audits, and implementing or ensuring implementation of corrective actions as needed to resolve any nonconformance issues noted during assessments.

- Ensuring data collected are of known and acceptable quality and adhere to QAPP specifications.

- Supervising laboratory personnel involved in laboratory analysis and preparation, deployment, and periodic cleaning of sensors.

- Ensuring laboratory personnel have adequate training and thorough knowledge of the QAPP and all standard operating procedures (SOPs) specific to the analyses or tasks performed and (or) supervised.

- Overseeing all CAL operations; ensuring that all QA/QC requirements are met and that all documentation related to laboratory procedures is completely and accurately reported; and ensuring that corrective actions are implemented, documented, reported, and verified.

The USGS SPCMSC Laboratory Manager is responsible for managing all SPCMSC laboratories and for personnel safety and ensures that all laboratory personnel involved have adequate laboratory safety training. The Laboratory Manger is also responsible for oversight of all CAL safety operations and ensures that documentation related to laboratory procedures is completely and accurately reported.

The CAL field, laboratory, and data technicians are responsible for assisting in all aspects of data collection, station service, and measurement of water chemical and physical parameters both in the field and in the laboratory. Each technician is also responsible for assisting the Field Supervisor with scheduling, staffing, and ensuring that staff are appropriately trained (see 
section 2.11) as well as coordinating joint monitoring with the TBEP Project Manager. The technicians report status, problems, and progress to the TBEP Project Manager. Additional responsibilities of the technicians include the following:

- Acquiring, verifying, and transferring data to the CAL database.

- Overseeing the project database following the guidelines of the Data Management Plan to archive all data in the SPCMSC database and transferring data to the TBEP in the acceptable format.

- Ensuring that all data-maintenance tasks are completed, providing the point of contact for the TBEP Project Manager, resolving issues related to the data, and assuming responsibility for correction of any data errors.

- Overseeing all aspects of sampling and measurement of water chemistry.

- Ensuring proper collection of field data in a timely manner, thereby meeting the quality objectives specified in sections 2.1 through 2.9 .

\subsubsection{Project Revisions}

During the course of the project, it is possible that procedural changes may be required. Project revisions are necessary to reflect changes in project organization, tasks, schedules, objectives, and methods; to address deficiencies and nonconformance; to improve operational efficiency; and (or) to accommodate unique or unanticipated circumstances. Requests for project revisions are directed from the USGS SPCMSC Project Manager to the TBEP Project Manager in writing and are reviewed and discussed by all parties involved.

Any changes to technical procedures are reviewed by the TBEP Project Manager, TBEP Quality Assurance Officer, and EPA Project Manager, who determine whether the changes affect the technical and quality objectives of the project and provide final approval of project modifications.

\section{Data Acquisition and Processing}

\subsection{Sampling Process Design}

The monitoring effort is carried out by collocating ocean chemistry monitoring equipment at a Tampa Bay PORTS station and at an additional near-coastal GOM COMPS station. The PORTS location (station number 8724612) is in the lower-middle part of Tampa Bay $\left(27^{\circ} 39^{\prime} 42.0^{\prime \prime} \mathrm{N}, 82^{\circ} 36^{\prime} 0.0^{\prime \prime} \mathrm{W}\right)$ in an area that is relatively constricted, centrally located, and wellmixed. The PORTS station provides meteorological data, including wind speed and direction, air temperature, barometric pressure, and visibility measurements, every 6 minutes. The PORTS station is located near a PORTS current meter (station number t03010). Coordination of water-quality data with hydrodynamic data enables characterization of the estuarine chemical signature during outgoing tides and the GOM signature during incoming tides. The PORTS station also provides a centralized point of reference for comparing experimental data from habitats along the periphery of Tampa Bay and at an additional monitoring site located in the GOM adjacent to Tampa Bay, near the COMPS C12 mooring location $\left(27^{\circ} 30^{\prime} 18.0^{\prime \prime} \mathrm{N}, 83^{\circ} 44^{\prime} 27.6^{\prime \prime} \mathrm{W}\right)$.

The project involves the collection of autonomous $\mathrm{pH} ; \mathrm{pCO}_{2}$; dissolved oxygen (DO); PAR; and conductivity, temperature, and depth (CTD) data using four in situ sensors that are 
assembled into a custom-designed platform designated the Ocean Carbonate System (OCS). Sensor specifications are available in appendix 1. The autonomous $\mathrm{pH}$ (total $\mathrm{pH}$ scale), CTD, and DO measurements are made using a Sea-bird Scientific SeapHOx sensor, which combines a Seabird Scientific SeaFET pH sensor with a Sea-Bird Scientific SBE 37-SMP-ODO MicroCAT CTD plus DO sensor. The $\mathrm{pCO}_{2}$ measurements are made using a Pro-Oceanus $\mathrm{CO}_{2}$-Pro $\mathrm{CV}$. The $\mathrm{pH}$ and $\mathrm{pCO}_{2}$ sensors also measure temperature because temperature is used in the internal computations of these instruments. Data collected by the sensors are saved in an in situ Sea-bird Scientific STOR-X data logger for periodic download. The SPCMSC staff manually download the data at least quarterly, perform primary and secondary QA/QC on the data, and prepare and release the data publicly as official USGS data releases that are available online. A cellular telemetry system is used to transmit data from the OCS to the USGS and TBEP offices, permitting frequent system checks. The monitoring effort also includes periodic, discrete measurements of $\mathrm{pH}$, dissolved inorganic carbon (DIC), and total alkalinity (TA) collected from the OCS sites and analyzed in the CAL. The samples will be collected for a period of at least 1 year from sensor deployment. Further data collection depends on the availability of additional funding.

All sensors should operate continuously for an initial period of 1 year under careful maintenance that includes monthly inspection and crosscheck with discrete water sampling. Upon completion of the first year, the sensors will be sent to their respective manufacturers for recalibration. Should sensors malfunction, corrective procedures will be taken, including diagnosis under the direction of the manufacturers. Discrete water sampling will be maintained to ensure continued $\mathrm{pH}, \mathrm{pCO}_{2}$, and $\mathrm{DO}$ records, albeit at lower temporal resolution. After the completion of the initial year of sampling, continued deployment of the sensors is conditional on the acquisition of further funding until the lifetimes of the sensors are reached or the sensors are replaced.

The project generates high-temporal-resolution (hourly) $\mathrm{pH}$ and $\mathrm{pCO}_{2}$ datasets. The data files contain the following columns:

- A date/time stamp in Eastern Standard Time (EST);

- Parameter values; and

- Data quality flags (the parameter header is preceded by "QF") to indicate the quality of the data using numerical codes 0 through 5 and 9. These flags are consistent with the National Oceanic and Atmospheric Administration National Centers for Environmental Information data quality flags and are defined in table 1.

Parameters reported by the sensors include the following:

- $\mathrm{pH}$ on the total scale;

- $\mathrm{pCO}_{2}$ in microatmopsheres ( $\left.\mu \mathrm{atm}\right)$ or parts per million (ppm);

- PAR in microeinsteins;

- Conductivity in siemens $(\mathrm{S})$ or millisiemens $(\mathrm{mS})$;

- Water temperature in degrees Celsius $\left({ }^{\circ} \mathrm{C}\right)$;

- Salinity in parts per thousand; and

- DO in micromoles per liter.

The in situ $\mathrm{pH}, \mathrm{pCO}_{2}$, and auxiliary data are recorded hourly using Sea-bird Scientific STOR-X data loggers at fixed monitoring sites located at or near PORTS and COMPS mooring buoys in lower-middle Tampa Bay and near-coastal GOM waters adjacent to Tampa Bay. 
Table 1. Data quality flags.

\begin{tabular}{lll}
\multicolumn{1}{c}{ Class } & \multicolumn{1}{c}{ Quality } & \multicolumn{1}{c}{ Description } \\
\hline Flag 0 & No quality control performed & $\begin{array}{c}\text { Flag } 0 \text { data are the level at which all data enter the working } \\
\text { archive. They have not yet been quality controlled. }\end{array}$ \\
Flag 1 & Good data & $\begin{array}{c}\text { Flag } 1 \text { indicates quality control has been performed and the } \\
\text { element appears to be correct. }\end{array}$ \\
Flag 2 & Probably good data & $\begin{array}{l}\text { Flag } 2 \text { indicates quality control has been performed and the } \\
\text { element appears to be probably good. }\end{array}$ \\
Flag 3 & Probably bad data & $\begin{array}{l}\text { Flag } 3 \text { indicates quality control has been performed and the } \\
\text { element appears to be probably bad. }\end{array}$ \\
Flag 4 & Flag 4 indicates quality control has been performed and the \\
& element appears to be bad. \\
Flag 5 & Flag 5 indicates the value has been modified as a result of \\
& quality control.
\end{tabular}

\subsection{Sampling Methods}

\subsubsection{Automated Sampling Procedures}

Prior to deployment, the internal clocks of the STOR-X data logger are set to local time (EST). All data from the OCS system are collected every hour at a water-column depth of approximately 1.0 to 3.0 meters below the sea surface. The STOR-X distributes power to the attached sensors according to a custom schedule, coordinates the acquisition times, and records data from all sensors with a common time and date stamp. The OCS operates 24 hours per day and has a sampling period once every hour at the half-hour mark prefaced by a 20 -minute warm-up period for the $\mathrm{CO}_{2}$-Pro $\mathrm{CV}$. Each sampling period runs for 1 minute and 10 seconds. During the sampling period, the $\mathrm{CO}_{2}$-Pro $\mathrm{CV}$, SeapHOx, and ECO-PAR sensors make multiple measurements. The $\mathrm{CO}_{2}$-Pro $\mathrm{CV}$ sensor re-zeros every 8 hours to minimize sensor drift.

The OCS system components are integrated into a custom configuration and custom packaged for attachment to mooring and buoy platforms (fig. 2A). A Sea-Bird Scientific 5-P pump is used to move water in and out of the $\mathrm{CO}_{2}$-Pro $\mathrm{CV}$ sensor. Outflow from the $\mathrm{CO}_{2}$-Pro $\mathrm{CV}$ is routed near the flowthrough cap of the SeapHOx for closely coupled $\mathrm{CO}_{2}$ and $\mathrm{pH}$ measurements. An example of this type of system is shown in figure $2 B$. 

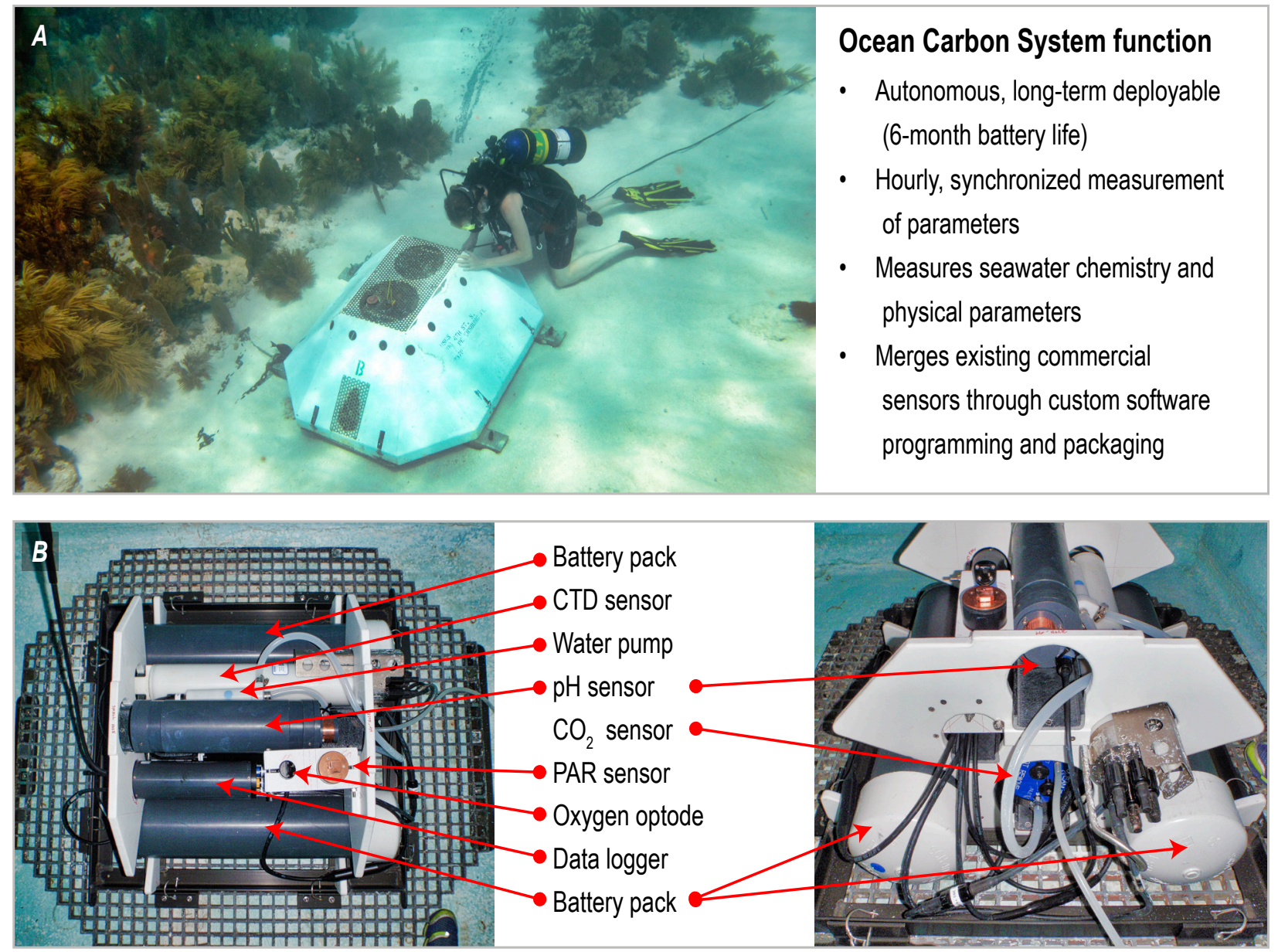

Figure 2. First generation Ocean Carbon System (OCS) housed inside of a trawl resistant mount on the seafloor $(A)$. The OCS system used for this project was constructed in a similar manner using the most recent models of similar sensors $(B)$. CTD, conductivity, temperature, and depth; DO, dissolved oxygen; PAR, photosynthetically active radiation; $\mathrm{pCO}_{2}$, partial pressure of carbon dioxide.

\subsubsection{Sensor Maintenance}

The OCS is serviced regularly by USGS staff. During each service, the OCS is cleaned to prevent biofouling. Sensor performance is evaluated using internal controls (such as known voltage and auxiliary data and duplicate measurements) and comparisons of discrete data. Quarterly maintenance may require temporary removal of one or more sensors for sensor-head polishing and (or) desiccant replacement.

\subsubsection{Recording Data}

The OCS data are managed and stored by the STOR-X data logger. Acquired data are saved as sensor-specific .raw files for each Julian day. The data are downloaded from the STOR-X at regular intervals to ensure the sensors' operational status. Downloading the .raw files from the STOR-X requires the use of STORXCom software to communicate between the STOR-X and a computer. Once the data have been downloaded, SatCon version 1.5 data-con- 
version software converts the .raw files into .dat files and applies basic preprocessing to convert individual .dat files into combined multiday datasets for each sensor. The .dat files are opened in Microsoft Excel and saved in .xlsx format. The combined multiday files contain header strings for each individual day file that must be removed manually in Microsoft Excel, leaving only the top header line. The multiday files are then processed through a custom averaging code written in Pearl that was designed by David Zawada of the USGS. This code averages the measurements to generate a single value for each sensor per sampling period. The average values are reported at the start time of the sampling period. In addition to averaging the measured values, the code also generates the mean, standard deviation, minimum, and maximum for each sampling period. These statistics are used to evaluate system performance. The averaged data for each sensor are then manually merged into a single .xlsx file for further processing. Data files are deleted from the STOR-X after successful download and storage of data have been confirmed. A general data management plan is available in appendix 2.

All personnel follow the basic rules for recording information in field notebooks as documented below:

- Notes are legibly written in pencil and without modifications in waterproof field notebooks. Recording errors are marked with write-overs or cross-outs in the project field notebook.

- Changes are made by crossing out original entries with a single line, entering the changes, and initialing and dating the corrections. No white out or other ink-covering pigment is used.

- Close-outs on incomplete pages are indicated with an initialed and dated diagonal line.

- Information entered into the project field notebook includes the date, the time of the activity, and a detailed description of the activity.

\subsubsection{Discrete Water Sampling}

Duplicate water samples for TA and DIC analysis are collected from the OCS using a permanently mounted sensor-to-surface sampling tube and a peristaltic pump. Seawater is pressure filtered through a 0.45 -micron cellulose nitrate filter in a filter housing mounted in line with the peristaltic pump to ensure exclusion of particulates from the samples. Water temperature and salinity data are collected using a YSI multiparameter meter that is calibrated the beginning of the day and deployed at the OCS depth. Water sample collection follows standard protocols for studies of ocean carbonate chemistry (Dickson and others, 2007). The samples are collected in 300-milliliter ( $\mathrm{mL}$ ) ground-glass borosilicate bottles, and overflow of at least one bottle volume is performed to rinse the bottle before collection of the sample. After sample collection, 100 microliters $(\mu \mathrm{L})$ of saturated mercuric chloride $\left(\mathrm{HgCl}_{2}\right)$ is injected into the sampling bottle to arrest biological activity, and Apiezon grease is applied to the bottle stopper. The bottle stopper is secured to the bottle using black tape to create a positive-pressure seal (see appendix 3 for the SOP). Details of these methodologies are also available at https:/coastal.er.usgs.gov/carbonlab/ samplingsupplies.html. The samples are collected for analysis of spectrophotometric $\mathrm{pH}$ from the sensor-to-surface sampling tube using 30-mL cuvettes. The $\mathrm{pH}$ samples are analyzed in the field within 1 hour of collection. The DIC and TA samples are transported to the CAL for analysis. 


\subsection{Sample Handling and Custody}

Water samples are stored in an insulated container to buffer temperature changes and are transferred to the CAL upon returning to shore. A chain-of-custody form is used to record sampling and analysis information. Physical copies of the chain-of-custody form (appendix 4), sampling form, and field notebook are maintained by the CAL laboratory manager and are copied to electronic form within 2 days of sample collection. Water samples are stored in permanently numbered bottles to avoid the loss of labeling stickers or ink, and the time of collection based on EST is recorded in YYMMDDHHMM format along with the sample number to allow for easy referencing with the time stamps of the sensor-recorded data.

\subsection{Analytical Methods}

\subsubsection{Total Alkalinity}

Samples are analyzed for TA (precision of approximately \pm 1 micromole per kilogram $[\mu \mathrm{mol} / \mathrm{kg}]$ ) according to the spectrophotometric methods of Yao and Byrne (1998) using an Ocean Optics USB2000 spectrophotometer and bromocresol purple indicator dye (see appendix 3 for the SOP).

\subsubsection{Dissolved Inorganic Carbon}

Samples are analyzed for DIC (precision of approximately $\pm 3 \mu \mathrm{mol} / \mathrm{kg}$ ) using a UIC, Inc. carbon coulometer model 5017L and acidification module following the methods of Dickson and others (2007) (see appendix 3 for the SOP).

Certified reference material (CRM) is obtained from Dr. Andrew Dickson's laboratory at the Scripps Institution of Oceanography and used to ensure the accuracy of both TA and DIC analyses.

\subsection{3 $\mathrm{pH}$}

Samples are analyzed for $\mathrm{pH}$ (precision of approximately \pm 0.005 ) within 1 hour of collection following the spectrophotometric methods of Zhang and Byrne (1996) using an Ocean Optics USB2000 spectrophotometer and thymol blue indicator dye (see appendix 5 for the SOP).

\subsection{Quality Control}

USGS SPCMSC field technicians adhere to manufacturers' guidelines in the preparation of $\mathrm{pH}$ and $\mathrm{pCO}_{2}$ sensors for field deployment and service. In the event of a discovery of a failure to comply with established quality-control procedures, corrective actions are made upon determination of the point of the failure. Should the failure be in the electronic process, repair or replacement of the suspected component(s) is warranted. Should the failure be due to faults of personnel, corrective action ranges from reinforcement of training to replacement of personnel. Equipment problems are documented in the field notebook, and the USGS SPCMSC Project Manager is notified upon the discovery of such problems, when corrective actions are taken, and when a final resolution is reached. 
All sensor data are subject to preliminary QA/QC within 1 week of quarterly retrieval. A two-step procedure is taken to remove outliers (see section 5.1). The first step includes flagging data that are beyond the measurement ranges of the sensors (for example, 6.5 to 9.0 for $\mathrm{pH}$ and 0 to $2,000 \mathrm{ppm}$ for $\mathrm{pCO}_{2}$ ) with a quality flag of 4 to indicate bad data. Next, the data are plotted to examine temporal trends and cross-correlation (for example, $\mathrm{pCO}_{2}$ versus $\mathrm{pH}$ ), because predictable relationships (linear and exponential) have been observed in previous discrete and autonomous measurements made in Tampa Bay. Data points that deviate from temporal and (or) correlation trends are flagged with a quality flag of 4 to indicate bad data. These data are not removed from the final datasets, but they are flagged in data releases. See section 5.1 for further details on data validation and verification.

\subsection{Instrument Testing, Inspection, and Maintenance}

All instruments used in the project are inspected upon arrival to the CAL. All components of the sensors are under limited manufacturer warranty. The OCS instrument sensors undergo laboratory validation in the CAL instrument test tank by cross-validating with discrete measurements of parameters. Additionally, the OCS sensors are cross-validated after initial deployment in the field and a 48-hour equilibration period through hourly, discrete measurements of parameters for the first full day after the equilibration period.

The laboratory instruments used for TA and DIC analysis measure CRMs a minimum of twice daily to validate instrument performance and establish correction factors. The carbon coulometers are serviced by the manufacturer approximately every other year. For $\mathrm{pH}$ analysis, no calibration is required for spectrophotometric measurements. The only daily maintenance of the spectrophotometer is to allow it to achieve a stable baseline after warming up and analyzing several repeat test samples to ensure precision. The YSI multiparameter meters used for discrete water sampling are calibrated on a daily basis. The final calculation of discrete TA, DIC, and $\mathrm{pH}$ values is based on temperature and salinity values measured by the OCS during collection of the discrete samples.

\subsection{Instrument Calibration}

Neither the SeapHOx pH sensor nor the $\mathrm{CO}_{2}$-Pro CV require end-user calibration because the manufacturers precalibrate the instruments and provide calibration coefficients that are saved in the instruments prior to shipment. Within the lifetime of these sensors, both sensors are shipped to the manufacturers for annual maintenance or recalibration as recommended to ensure optimal instrument performance.

\subsection{Inspection of Supplies and Consumables}

The laboratory manager of the CAL is responsible for ordering and receiving necessary chemical reagents, including CRM seawater obtained from the Scripps Institution of Oceanography. The batch numbers and receiving dates of CRM are recorded. Upon arrival to the CAL, supplies are inspected to ensure there are no broken bottles of CRM and that other reagents and consumables are not damaged or outdated. Certified information on the DIC and TA of each CRM batch is provided on the National Oceanic and Atmospheric Administration National Centers for Environmental Information website (https://www.nodc.noaa.gov/ocads/oceans/Dickson_CRM/batches.html) and is maintained indefinitely. CRMs should be stored at room temperature in the dark. 


\subsection{Data Management}

Data from the OCS sensors are downloaded to a personal computer during every quarterly field maintenance trip. All raw data are saved and are never erased or expunged for any reason. The raw files are not modified and are stored in the original format in the USGS data archive within 48 hours of retrieval. All subsequent processing is performed on copies of these original files. The Data Management Plan is described in appendix 2.

The results of all discrete water samples are recorded in laboratory instrument log books and in digital format during the QA/QC process. Laboratory technicians transfer these records to the project folder saved in the CAL database. Upon completion of the project, the CAL field notebooks and sample results records are kept in the USGS data archive. All CAL-generated data are available to TBEP inspectors in physical and digital format during the course of the project.

\subsection{Data-Quality Objectives and Criteria}

The project objective is to collect carbonate system data that comply with EPA rules for surface-water-quality monitoring programs and water-quality assessments to support decisions related to mission objectives. The measurement methods used to support the project are described in table 2. Additional sensor specifications are provided in appendix 1.

\subsubsection{Reporting Limits}

The field reporting limits are determined by the resolution and accuracy of the sensors used for the project. These data can be found in the SeapHOx and $\mathrm{CO}_{2}$-Pro CV specification sheets (see appendix 1).

\subsubsection{Accuracy}

According to the specifications of the SeapHOx and the $\mathrm{CO}_{2}$-Pro $\mathrm{CV}$, the $\mathrm{pH}$ and $\mathrm{pCO}_{2}$ sensors have accuracies of \pm 0.05 and 0.5 percent of the measured value, respectively.

Because of the potential for signal drift and biofouling problems, we ensure data quality by using laboratory-grade instruments to perform validations of autonomous data through measurement of discrete water samples collected from the OCS deployment sites. As described in section 2.6, accuracy of the measurements is ensured by using CRM for analysis of DIC and TA.

\subsubsection{Precision}

The precision of data is a measure of the reproducibility of a measurement and includes components of random error. Precision is strictly defined as a measure of the closeness with which multiple analyses of a given sample agree with each other. For this reason, the method used to collect autonomous data from $\mathrm{pH}$ and $\mathrm{pCO}_{2}$ sensors in the field is to average a minimum of five consecutive measurements made by the sensors at their respective maximum sampling frequencies. These measurements are collected during every sampling interval and used to assess the performance of the instruments during preliminary QA/QC analysis. Should extreme variations occur, the sensors are checked to verify their proper functionality, and service is conducted depending on the nature of the problem. 
Table 2. Performance specifications indicating range of measurement for field instruments.

\begin{tabular}{lllll}
\hline \multicolumn{1}{c}{ Parameter } & \multicolumn{1}{c}{ Units } & \multicolumn{1}{c}{ Method } & Method description & Performance specifications \\
\hline $\mathrm{pH}$ & $\begin{array}{c}\text { Not applicable (on } \\
\text { total pH scale) }\end{array}$ & $\begin{array}{c}\text { Potentiometric } \\
\text { sensor }\end{array}$ & SeapHOx & $6.5-9.0$ \\
$\mathrm{CO}_{2}$ & $\begin{array}{c}\text { Parts per million } \\
(\mathrm{ppm})\end{array}$ & $\begin{array}{c}\text { Non-dispersive } \\
\text { infrared detection }\end{array}$ & $\mathrm{CO}_{2}$-Pro CV & $0-2,000$ parts per million \\
\hline
\end{tabular}

\subsubsection{Bias}

Bias is a statistical measurement of correctness and includes components of systemic error. A measurement is considered unbiased when the value reported does not differ from the true value. Regular checks for biases are conducted when the sensors are deployed using discrete samples that are collected at the OCS location approximately once every 3 weeks and analyzed in the CAL.

The data are deemed biased if the sensor-collected values deviate from $\pm 0.05 \mathrm{pH}$ unit for $\mathrm{pH}$ and \pm 3.0 percent for $\mathrm{pCO}_{2}$.

\subsubsection{Representativeness}

Data collected following the procedures in this QAPP are considered representative of ambient water-quality conditions. Representativeness is a measure of how accurately a monitoring program reflects the actual water-quality conditions. The representativeness of the data is dependent on (1) the sampling locations, (2) the number of samples collected, (3) the number of years and seasons when sampling is performed, and (4) the sampling procedures. Careful site selection and sampling of all pertinent media and the use of only approved analytical methods ensures that the data represent the conditions at the site.

\subsubsection{Comparability}

The comparability of the data is predetermined by the commitment of the staff to use only approved procedures as described in this QAPP. Comparability is also guaranteed by reporting data in standard units, by using accepted rules for rounding figures, and by reporting data in a standard format as specified in the Data Management Plan (appendix 2).

\subsubsection{Completeness}

The completeness of the data is a measure of how much of the data are available for use compared to the total potential data. Ideally, 100 percent of the data should be available; however, the possibility of incomplete data collection due to biofouling and routine maintenance for optimal sensor function is to be expected. Therefore, it is a general goal of the project to achieve a data collection rate of 80 percent or higher.

\subsection{Personnel Training}

Before sampling and field analysis occur, field personnel (USGS SPCMSC) receive training and demonstrate to the SPCMSC Quality Assurance Officer their ability to properly calibrate field 
equipment and perform field sampling and analysis procedures. The training is documented, and records are retained in the SPCMSC personnel files and are available during monitoring-systems audits.

Laboratory personnel have a combination of experience, education, and training to demonstrate knowledge of their responsibilities. A record of qualifications and training for each employee is maintained by the CAL laboratory manager, and the records are available for review during monitoring-systems audits.

\section{Documents and Records}

The documents and records that describe, specify, report, or certify the activities, requirements, procedures, and results for the project are listed in table 3. The project PI is responsible for ensuring that all project personnel have the most recent version of the QAPP, including any amendments and updates. Timely email communication with project personnel ensures that EPA and TBEP staff have the most recent version of the QAPP. Deliverables for the project include

Table 3. Documents and record retention information.

[QAPP, Quality Assurance Project Plan; USGS, U.S. Geological Survey; SPCMSC, St. Petersburg Coastal and Marine Science Center; SOP, standard operating procedure]

\begin{tabular}{|c|c|c|c|}
\hline Document/Record & Location & Retention & Form \\
\hline $\begin{array}{l}\text { QAPP, including amendments and } \\
\text { appendixes }\end{array}$ & USGS SPCMSC & 5 Years & Electronic and (or) paper \\
\hline QAPP distribution documentation & USGS SPCMSC & 5 Years & Electronic and (or) paper \\
\hline Field notebooks and field data sheets & USGS SPCMSC & 5 Years & Electronic and (or) paper \\
\hline $\begin{array}{l}\text { Field equipment calibration and } \\
\text { maintenance } \operatorname{logs}\end{array}$ & USGS SPCMSC & 5 Years & Electronic and (or) paper \\
\hline Chain-of-custody forms & USGS SPCMSC & 5 Years & Electronic and (or) paper \\
\hline Field sampling SOPs & USGS SPCMSC & 5 Years & Electronic and (or) paper \\
\hline $\begin{array}{l}\text { Field personnel demonstration of } \\
\text { capability }\end{array}$ & USGS SPCMSC & 5 Years & Electronic and (or) paper \\
\hline $\begin{array}{l}\text { Field personnel corrective action } \\
\text { documentation }\end{array}$ & USGS SPCMSC & 5 Years & Electronic and (or) paper \\
\hline Laboratory SOPs & USGS SPCMSC & 5 Years & Electronic and (or) paper \\
\hline Instrument raw data files & USGS SPCMSC & 5 Years & Electronic and (or) paper \\
\hline Instrument readings/printouts & USGS SPCMSC & 5 Years & Electronic and (or) paper \\
\hline Laboratory equipment maintenance logs & USGS SPCMSC & 5 Years & Electronic and (or) paper \\
\hline Laboratory calibration records & USGS SPCMSC & 5 Years & Electronic and (or) paper \\
\hline SPCMSC database verification & USGS SPCMSC & 5 Years & Electronic and (or) paper \\
\hline SPCMSC data-quality assurance & USGS SPCMSC & 5 Years & Electronic and (or) paper \\
\hline Quality-control verification/validation & USGS SPCMSC & 5 Years & Electronic and (or) paper \\
\hline Final report/data & USGS SPCMSC & 5 Years & Electronic and (or) paper \\
\hline
\end{tabular}


quarterly progress reports, a draft QAPP, a final QAPP, a draft report, and a final report. An example schedule of the project deliverables is presented in table 4.

After QA/QC, the project data are archived in the USGS SPCMSC database and delivered to both TBEP and EPA staff as USGS data releases. These data releases are published online and are available to the public indefinitely.

\section{Assessment, Oversight, and Reports to Management}

\subsection{Reports to the Tampa Bay Estuary Program}

All reports detailed in this section are contract deliverables and are sent to the TBEP in accordance with contract requirements. Project assessments, reports, and response actions are summarized in table 5. These reports include the following:

- Quarterly progress reports - Summarize the CAL activities for each task; report problems, delays, and corrective actions; and outline the status of each task's deliverables.

- Monitoring systems audit responses - The CAL staff respond to the TBEP in writing within 30 days upon receipt of a monitoring-systems audit report to address corrective actions.

- Final project report-Summarizes the CAL activities for the entire project period, including descriptions and documentation of major project activities, evaluation of the project results and environmental benefits, and conclusions.

\subsection{Reports from the Carbon Analytical Laboratory}

The CAL project staff provide project status reports, assessments results, and substantial QA issues relevant to project management to the TBEP Project Manager. These reports are written and oral and summarize progress toward the project's scope of work and deliverables.

\subsection{Reports to the U.S. Environmental Protection Agency}

- Monitoring-systems audit reports - Following any audit performed by the TBEP, a report of findings, recommendations, and response, is sent to the EPA Project Manager in a quarterly progress report from the TBEP.

- Quarterly progress reports - Summarize the CAL activities for each task; report problems, delays, and corrective actions; and outline the status of each task's deliverables. These reports are submitted to TBEP Project Manager and then sent to the EPA Project Manager.

Table 4. Project deliverables and tentative schedule.

\begin{tabular}{ll}
\hline \multicolumn{1}{c}{ Work Product } & \multicolumn{1}{c}{ Schedule of deliverables } \\
\hline Quality Assurance Project Plan & Within 30 days of sensor delivery \\
Quarterly progress reports & December 10, March 10, June 10, September 10 each year \\
Draft report & December 10 of the final project year \\
Final report & January 30 after the final project year \\
\hline
\end{tabular}


Table 5. Project assessment activities, reports, and response actions.

[QAPP, Quality Assurance Project Plan; TBEP, Tampa Bay Estuary Program; USGS, U.S. Geological Survey; SPCMSC, St. Petersburg Coastal and Marine Science Center; SOP, standard operating procedure]

\begin{tabular}{|c|c|c|c|c|}
\hline Assessment activity & Approximate schedule & Responsible party & Scope & Response requirements \\
\hline $\begin{array}{l}\text { Status monitoring } \\
\text { oversight }\end{array}$ & After QAPP approval & $\begin{array}{l}\text { TBEP and USGS } \\
\text { SPCMSC Project } \\
\text { Managers }\end{array}$ & $\begin{array}{l}\text { Monitoring of the } \\
\text { project status and } \\
\text { records to ensure the } \\
\text { project requirements } \\
\text { are being fulfilled }\end{array}$ & $\begin{array}{l}\text { Report to the TBEP in } \\
\text { a quarterly progress } \\
\text { report }\end{array}$ \\
\hline $\begin{array}{l}\text { Laboratory } \\
\text { inspections }\end{array}$ & $\begin{array}{l}\text { Dates to be } \\
\text { determined by the } \\
\text { TBEP }\end{array}$ & $\begin{array}{l}\text { TBEP and USGS } \\
\text { SPCMSC Project } \\
\text { Managers }\end{array}$ & $\begin{array}{l}\text { Ensure Laboratory } \\
\text { SOPs are observed }\end{array}$ & $\begin{array}{l}30 \text { days to respond in } \\
\text { writing to the TBEP } \\
\text { to address corrective } \\
\text { actions }\end{array}$ \\
\hline $\begin{array}{l}\text { Monitoring-systems } \\
\text { audits }\end{array}$ & $\begin{array}{l}\text { Dates to be } \\
\text { determined by the } \\
\text { TBEP }\end{array}$ & $\begin{array}{l}\text { TBEP Project } \\
\text { Manager }\end{array}$ & $\begin{array}{l}\text { The assessment will be } \\
\text { tailored in accordance } \\
\text { with data-collection } \\
\text { objectives }\end{array}$ & $\begin{array}{l}30 \text { days to respond in } \\
\text { writing to the TBEP } \\
\text { Quality Assurance } \\
\text { Officer to address } \\
\text { corrective actions }\end{array}$ \\
\hline Site visits & $\begin{array}{l}\text { Dates to be } \\
\text { determined by the } \\
\text { TBEP }\end{array}$ & $\begin{array}{l}\text { TBEP Project } \\
\text { Manager }\end{array}$ & $\begin{array}{l}\text { Status of activities and } \\
\text { overall compliance } \\
\text { with the work plan } \\
\text { and QAPP }\end{array}$ & As needed \\
\hline
\end{tabular}

\section{Data Review, Verification, and Validation}

Using electronic instrumentation for data collection has become an invaluable tool, allowing for continual, unattended monitoring. Proper instrument functionality is paramount for accurate data collection. The instruments used in the project are calibrated by their respective manufacturers, which recommend annual factory maintenance or recalibration. To ensure continuity of data collection, $\mathrm{pH}$ and $\mathrm{pCO}_{2}$ data collected by the sensors in the field are compared to discrete $\mathrm{pH}$ values and $\mathrm{pCO}_{2}$ values based on $\mathrm{pH}$ and DIC (input variables) that are calculated using the program CO2SYS (Pierrot and others, 2006). In cases of temperature discrepancy (greater than $0.1^{\circ} \mathrm{C}$ ) between the thermistors in both instruments and in situ seawater as measured by the YSI multiparameter instrument, $\mathrm{pH}$ and $\mathrm{pCO}_{2}$ values of discrete samples are corrected to in situ temperature measured by the OCS using CO2SYS. Any potential precision and bias issues are checked with discrete water samples following the description in section 2.10.

All data obtained from field measurements and laboratory calibrations are reviewed and verified for conformance with project requirements. Only those data that are supported by appropriate quality-control data and meet the measurement performance specification defined for the project are considered acceptable and used for final analyses.

The procedures for verification and validation of data are described in section 5.1. The USGS SPCMSC Project Manager is responsible for ensuring that field data are properly reviewed and verified for integrity and ensuring that laboratory data are scientifically valid, defensible, of acceptable precision and bias, and reviewed for integrity. The USGS SPCMSC Project Manager 
is also responsible for ensuring that all data are submitted to the project database in the required format. Finally, the CAL Project Manager is responsible for validating that all data to be reported meet the objectives of the project and are suitable for reporting to the TBEP.

\subsection{Data Validation and Verification Methods}

Review of data is performed using self-assessments and peer review, as appropriate to the project task, followed by technical review by the manager of the task. Data validation is performed through quarterly quality control of all sensor-generated data using discrete data collected approximately once every 3 weeks.

Upon retrieval of sensor data (the data are downloaded from sensors directly during quarterly maintenance), the data files are checked for the completeness of the data records to ensure that (1) the number of data fields equals the expected number of measured parameters for each record; and (2) there are no missing sequential data values. Next, range tests are performed by comparing recorded data with the allowable upper and lower limits of sensor measurements (see section 2.5 for details). Relational tests are performed using the observed sensor data to reject outlier data. Data QA is performed using sensor-generated data and data from discrete samples. Laboratory-measured $\mathrm{pH}$ and $\mathrm{pCO}_{2}$ calculated using DIC and $\mathrm{pH}$ are compared with sensor-generated data to ensure that the sensors are working within the specified accuracies. The data are evaluated and flagged as indicated in section 2.1.

If a question arises or an error is identified, the staff member responsible for generating the data is contacted to resolve the issue. Issues that can be resolved are corrected and documented electronically or by initialing and dating the associated records. If an issue cannot be corrected, the manager of the task consults with higher-level project management to establish the appropriate course of action. All field and laboratory reviews, verifications, and validations are documented.

The USGS SPCMSC Project Manager and the TBEP Quality Assurance Officer are responsible for validating that the verified data are scientifically valid; are defensible; are of known precision, bias, and integrity; meet the data-quality objectives of the project; and are suitable for reporting to the TBEP. Before data validation can be completed, all suspected errors or anomalous data are addressed by the manager of the task associated with the data.

The second element of the validation process is the consideration of any findings identified during monitoring-systems audits conducted by the TBEP Project Manager. Any issues requiring corrective action are addressed, and the potential effects of these issues on previously collected data are assessed. Finally, the USGS SPCMSC Project Manager, with the concurrence of the TBEP Quality Assurance Officer, validates that the data meet the data-quality objectives of the project and are suitable for reporting to the TBEP.

All data are verified to ensure they are representative of the in situ measurements and that the data and associated quality-control data conform to the project specifications. The staff and managers of the respective field, laboratory, and data-management tasks are responsible for the integrity, validation, and verification of the data generated or handled during each task throughout each process. The field and laboratory tasks ensure the verification of calibration and in situ data.

\subsection{Reconciliation with User Requirements}

Data collected during the course of the project are analyzed by personnel at the CAL and the TBEP to reconcile data needs with user requirements. The objectives are to examine carbonate-chemistry variation on different time scales, for example, daily variations that are 
the result of tidal influence, production, and respiration and seasonal or interannual variations influenced by freshwater inflow and coastal and ocean acidification.

\section{References Cited}

Anthony, K.R.N., Kleypas, J.A., and Gattuso, J.-P., 2011, Coral reefs modify their seawater carbon chemistry-Implications for impacts of ocean acidification: Global Change Biology, v. 17, no. 12, p. 3655-3666. [Also available at https://doi.org/10.1111/j.1365-2486.2011.02510.x.]

Dickson, A.G., Sabine, C.L., and Christian, J.R., eds., 2007, Guide to best practices for ocean acidification $\mathrm{CO}_{2}$ measurements: North Pacific Marine Science Organization, Special Publication 3, 191 p., accessed April 10, 2018, at https://www.nodc.noaa.gov/ocads/oceans/Handbook_2007/ Guide_all_in_one.pdf.

Brooks, G.R., and Doyle, L.J., 1998, Recent sedimentary development of Tampa Bay, Florida-A microtidal estuary incised into Tertiary platform carbonates: Estuaries, v. 21, no. 3, p. 391-406. [Also available at https://doi.org/10.2307/1352838.]

Hendriks, I.E., Olsen, Y.S., Ramajo, L., Basso, L., Steckbauer, A., Moore, T.S., Howard, J., and Duarte, C.M., 2014, Photosynthetic activity buffers ocean acidification in seagrass meadows: Biogeosciences, v. 11, no. 2, p. 333-346. [Also available at https://doi.org/10.5194/bg-11-333-2014.]

Kleypas, J.A., and Yates, K.K., 2009, Coral reefs and ocean acidification: Oceanography, v. 22, no. 4, p. 108-117. [Also available at https://doi.org/10.5670/oceanog.2009.101.]

Manzello, D.P., Enochs, I.C., Melo, N., Gledhill, D.K., and Johns, E.M., 2012, Ocean acidification refugia of the Florida Reef Tract: PLoS ONE, v. 7, no. 7, 10 p., accessed April 10, 2018, at https://doi.org/10.1371/journal.pone.0041715.

Pierrot, D., Lewis, E., and Wallace, D.W.R., 2006, MS Excel program developed for $\mathrm{CO}_{2}$ system calculations: Oak Ridge, Tenn., Carbon Dioxide Information Analysis Center, Oak Ridge National Laboratory, ORNL/CDIAC-105a, accessed April 10, 2018, at http://cdiac.ess-dive.lbl.gov/ftp/ co2sys/CO2SYS_calc_XLS_v2.1/.

Semesi, I.S., Beer, S., and Bjork, M., 2009, Seagrass photosynthesis controls rates of calcification and photosynthesis of calcareous macroalgae in a tropical seagrass meadow: Marine Ecology Progress Series, v. 382, p. 41-47. [Also available at https://doi.org/10.3354/meps07973.]

Sherwood, E.T., Greening, H.S., Janicki, A.J., and Karlen, D.J., 2016, Tampa Bay estuary-Monitoring long-term recovery through regional partnerships: Regional Studies in Marine Science, v. 4, p. 1-11. [Also available at https://doi.org/10.1016/j.rsma.2015.05.005.]

Yao, W., and Byrne, R.H., 1998, Simplified seawater alkalinity analysis-Use of linear array spectrometers: Deep-Sea Research Part 1: Oceanographic Research Papers, v. 45, no. 8, p. 1383-1392. [Also available at https://doi.org/10.1016/S0967-0637(98)00018-1.]

Yates, K.K., Moyer, R.P., Tomasko, D., Smiley, N., Torres-Garcia, L., Powell, C.E., Chappel, A.R., and Bociu, I., 2016, Ocean acidification buffering effects of seagrass in Tampa Bay, in Burke, M. (ed.), Proceedings of the sixth Tampa Bay Area Scientific Information Symposium, St. Petersburg, Fla., September 28-30, 2015: St. Petersburg, Fla., Tampa Bay Estuary Program, p. 273-284, accessed April 10, 2018, at http://www.tbeptech.org/data/tbep-basis/213-6th-bay-areascientific-information-symposium-proceedings.

Zhang, H., and Byrne, R.H., 1996, Spectrophotometric pH measurements of surface seawater at in-situ conditions-Absorbance and protonation behavior of thymol blue: Marine Chemistry, v. 52, no. 1, p. 17-25. [Also available at https://doi.org/10.1016/0304-4203(95)00076-3.] 


\section{Appendix 1. Sensor Specifications}

The Sea-bird Scientific SeapHOx sensor combines the SeaFET $p H$ sensor with the SBE 37-SMP-ODO MicroCAT conductivity, temperature, and depth (CTD) plus dissolved oxygen (DO) sensor. The specifications for the SeapHOx are provided in table 1.1. The specifications for the Pro-Oceanus $\mathrm{CO}_{2}$-Pro CV sensor, WetLabs ECO-PAR sensor, and Sea-bird Scientific STOR-X submersible data logger are provided in tables 1.2, 1.3, and 1.4, respectively.

Table 1.1. Specifications for the Sea-bird Scientific SeapHOx sensor.

$\left[\mathrm{S} / \mathrm{m}\right.$, siemens per meter; $\mathrm{mS} / \mathrm{cm}$, millisiemens per centimeter; ${ }^{\circ} \mathrm{C}$, degree Celsius; $\mathrm{m}$, meter; $\mu \mathrm{mol} / \mathrm{kg}$, micromole per kilogram; $\mathrm{mL} / \mathrm{L}, \mathrm{milliliter}$ per liter; mg/L, milligram per liter; GB, gigabyte; VDC, volt direct current; USB, Universal Serial Bus; kg, kilogram; mm, millimeter; in, inch]

\begin{tabular}{|c|c|}
\hline \multicolumn{2}{|r|}{ Measurement ranges } \\
\hline $\mathrm{pH}$ & 6.5 to 9.0 \\
\hline Conductivity & 0 to $7 \mathrm{~S} / \mathrm{m}(0$ to $70 \mathrm{mS} / \mathrm{cm})$ \\
\hline Temperature & -5 to $45^{\circ} \mathrm{C}$ \\
\hline Pressure & 20 or $100 \mathrm{~m}$ \\
\hline Dissolved oxygen & 120 percent of surface saturation in all natural waters (fresh and salt) \\
\hline \multicolumn{2}{|r|}{ Initial accuracy } \\
\hline $\mathrm{pH}$ & \pm 0.05 \\
\hline Conductivity & $\pm 0.0003 \mathrm{~S} / \mathrm{m}(0.003 \mathrm{mS} / \mathrm{cm})$ \\
\hline Temperature & $\pm .002{ }^{\circ} \mathrm{C}\left(-5\right.$ to $\left.35^{\circ} \mathrm{C}\right) ; \pm 0.01{ }^{\circ} \mathrm{C}\left(35^{\circ} \mathrm{C}\right.$ to $\left.45^{\circ} \mathrm{C}\right)$ \\
\hline Pressure & \pm 0.1 percent of full scale range \\
\hline Dissolved oxygen & $\pm 3 \mu \mathrm{mol} / \mathrm{kg}(0.07 \mathrm{~mL} / \mathrm{L}, 0.1 \mathrm{mg} / \mathrm{L})$ or \pm 2 percent (whichever is larger) \\
\hline \multicolumn{2}{|r|}{ Typical stability } \\
\hline $\mathrm{pH}$ & 0.003 per month \\
\hline Conductivity & $0.0003 \mathrm{~S} / \mathrm{m}(0.003 \mathrm{mS} / \mathrm{cm})$ per month \\
\hline Temperature & $0.0002{ }^{\circ} \mathrm{C}$ per month \\
\hline Pressure & 0.05 percent of full scale range per year \\
\hline Dissolved oxygen & Sample-based drift $<1 \mu \mathrm{mol} / \mathrm{kg}\left(20^{\circ} \mathrm{C}\right)$ \\
\hline \multicolumn{2}{|r|}{$\begin{array}{l}\text { Resolution } \\
\end{array}$} \\
\hline $\mathrm{pH}$ & 0.004 \\
\hline Conductivity & $0.00001 \mathrm{~S} / \mathrm{m}(0.0001 \mathrm{mS} / \mathrm{cm})$ \\
\hline Temperature & $0.0001^{\circ} \mathrm{C}$ \\
\hline Pressure & 0.002 percent of full scale range \\
\hline Dissolved oxygen & $0.2 \mu \mathrm{mol} / \mathrm{kg}$ \\
\hline \multicolumn{2}{|r|}{ Miscellaneous } \\
\hline Internal memory & $4 \mathrm{~GB}$ \\
\hline Supply voltage range & 6 to $18 \mathrm{VDC}$ \\
\hline \multicolumn{2}{|r|}{ Measurement ranges } \\
\hline Communication & RS-232, USB \\
\hline Weight (with batteries) & $5.4 \mathrm{~kg}$ in air; $0.1 \mathrm{~kg}$ in water \\
\hline Dimensions (housing) & $508 \mathrm{~mm}$ (20 in) x $114 \mathrm{~mm}(4.8 \mathrm{in})$ \\
\hline Maximum depth & $50 \mathrm{~m}$ \\
\hline
\end{tabular}


Table 1.2. Specifications for the Pro-Oceanus $\mathrm{CO}_{2}-$ Pro $\mathrm{CV}$ sensor.

[ $\mu$ atm, microatmosphere; ppm, part per million; s, second; m, meter, ${ }^{\circ} \mathrm{C}$, degree Celsius; cm, centimeter; $\mathrm{kg}$, kilogram]

\begin{tabular}{ll}
\hline \multicolumn{2}{c}{ Specifications } \\
\hline Typical calibration range & 0 to $2,000 \mu \mathrm{atm}$ \\
Resolution & $0.01 \mathrm{ppm}$ \\
Accuracy & \pm 0.5 percent \\
Drift & 0, automatic zero compensation \\
Equilibration time & $50 \mathrm{~s}$ \\
Depth limit & $600 \mathrm{~m}$ \\
Temperature limit & 15 to $40{ }^{\circ} \mathrm{C}$ (tropical) \\
Dimensions (housing & $55 \mathrm{~cm}, 15.2 \mathrm{~cm}$ \\
length, diameter) & \\
Weight in air/seawater & $7.6 \mathrm{~kg} / 1.1 \mathrm{~kg}$ \\
\hline
\end{tabular}

Table 1.3. Specifications for the WetLabs ECO-PAR sensor.

$\left[\mathrm{mm}^{2}\right.$, square millimeter; $\mathrm{m}$, meter; $\mathrm{nm}$, nanometer; Hz, hertz; ${ }^{\circ} \mathrm{C}$, degree Celsius; $\mathrm{cm}$, centimeter; kg, kilogram]

\begin{tabular}{|c|c|}
\hline \multicolumn{2}{|c|}{ Specifications } \\
\hline Collector area & $86 \mathrm{~mm}^{2}$ \\
\hline Depth range & $300 \mathrm{~m}$ \\
\hline Field of view & $\begin{array}{l}\text { Cosine response (within } 3 \\
\text { percent at } 60 \text { degrees) }\end{array}$ \\
\hline $\begin{array}{l}\text { Photosynthetically active } \\
\text { radiation }\end{array}$ & 400 to $700 \mathrm{~nm}$ \\
\hline Antifoulant & Bio-wiper \\
\hline Sample rate & To $8 \mathrm{~Hz}$ \\
\hline Temperature range & 0 to $30^{\circ} \mathrm{C}$ \\
\hline $\begin{array}{l}\text { Dimensions (housing } \\
\text { length, diameter) }\end{array}$ & $12.7 \mathrm{~cm}, 6.3 \mathrm{~cm}$ \\
\hline Weight in air/seawater & $0.4 \mathrm{~kg} / 0.02 \mathrm{~kg}$ \\
\hline
\end{tabular}

Table 1.4. Specifications for the Sea-bird Scientific STOR-X submersible data logger.

[VDC, volt direct current; ${ }^{\circ} \mathrm{C}$, degree Celsius; MB, megabyte; cm, centimeter; kg, kilogram; m, meter]

\begin{tabular}{ll}
\hline \multicolumn{1}{c}{ Specifications } \\
\hline Input voltage & 6 to $18 \mathrm{VDC}$ \\
Temperature range & -2.5 to $40^{\circ} \mathrm{C}$ \\
Memory capacity & $256 \mathrm{MB}$ Expandable \\
Physical dimensions (length, diameter) & $28.6 \mathrm{~cm}, 8.9 \mathrm{~cm}$ \\
Weight & $1.75 \mathrm{~kg}$ \\
Depth rating & $60 \mathrm{~m}$ \\
Communication & $\mathrm{RS}-232, \mathrm{RS}-422$, or 0 to $5 \mathrm{VDC}$ analog \\
Number of ports & 5 \\
Connector type & 6 Pin MC-BH-6F \\
\hline
\end{tabular}




\section{Appendix 2. Data Management Plan}

Primary Investigator: Kimberly Yates

Institution: U.S. Geological Survey (USGS), St. Petersburg Coastal and Marine Science Center Project Title: Tampa Bay Ocean and Coastal Acidification Monitoring

Submission Date: July 10, 2017

Overview: This project examines temporal variations in $\mathrm{pH}$, partial pressure of carbon dioxide $\left(\mathrm{pCO}_{2}\right)$, and supporting water-quality parameters in the Tampa Bay estuary.

Data description: Data are obtained from autonomous sensors placed at existing Tampa Bay Physical Oceanographic Real-Time System (PORTS) and Coastal Ocean Monitoring and Prediction System (COMPS) moorings and from discrete water sampling conducted at the same locations. The measured values include $\mathrm{pH}, \mathrm{pCO}_{2}$, photosynthetically active radiation (PAR), dissolved oxygen (DO), temperature, salinity, conductivity, and pressure.

Data analysis summary: Primary Investigator Yates and her team are responsible for all data collection and analysis.

Includes field/experimental work: Fieldwork

Description of field/experimental work: Yates' group conducts monthly (at minimum) trips to the Ocean Carbon System (OCS) mooring stations to collect discrete samples for sensor validation and to maintain the OCS. The data are downloaded from the OCS quarterly. In the Carbon Analytical Laboratory, Yates' group performs analyses on the discrete water samples.

Expected data product \#1

Data type: Observational, Analytical

Responsible investigator: Kimberly Yates

Product description: Water carbonate chemistry data including total alkalinity, total dissolved inorganic carbon, and $\mathrm{pH}$ (spectrophotometric method on total scale) are measured in discrete samples. Sensor data ( $\mathrm{pH}, \mathrm{pCO}_{2}, \mathrm{DO}, \mathrm{PAR}$, temperature, salinity, conductivity, and pressure) are recorded on hourly intervals. These data are saved in comma-delimited format (.csv) and are published online as USGS data releases that are available to the public. Draft data releases are submitted to the Tampa Bay Estuary Program (TBEP) for review prior to publication.

Timeline for data release: Data are submitted to the TBEP and the U.S. Environmental Protection Agency quarterly, following quality assurance and quality control.

Intended Repository: USGS Archive and (or) Pangaea, National Oceanic and Atmospheric Administration National Centers for Environmental Information, or DataOne/Knowledge Network for Biocomplexity.

Expected Data: We anticipate that the project work will generate less than 10 gigabytes of data. 


\section{Appendix 3. Water Sampling Protocol for Total Alkalinity, Dissolved Inor- ganic Carbon, and pH Analyses}

\section{Introduction}

This appendix describes a method for the collection of discrete $\mathrm{pH}$, total alkalinity (TA), and dissolved inorganic carbon (DIC) samples. The samples are analyzed in the U.S. Geological Survey (USGS) Carbon Analytical Laboratory (CAL). Using any two of three measured values $\left(\mathrm{pH}\right.$, partial pressure of carbon dioxide $\left[\mathrm{pCO}_{2}\right]$, and TA), calculations can be performed for the entire carbonate system. TA and DIC are analyzed using the same sample aliquot, whereas $\mathrm{pH}$ on the total scale $\left(\mathrm{pH}_{\mathrm{T}}\right)$ is analyzed using a separately collected seawater sample. The data are used to verify the measurements taken by the automated, in situ sensors.

\section{Apparatus}

\section{Sample Bottles}

Borosilicate glass biological oxygen demand (BOD) bottles (300-milliliter [mL] or 500$\mathrm{mL}$ volume) with ground-glass stoppers are prepared for use by hand washing with liquinox laboratory soap to remove Apiezon grease from the previous sampling. The bottles are rinsed three times with tap water. The washed bottles are combusted at 565 degrees Celsius $\left({ }^{\circ} \mathrm{C}\right)$ for 3 hours to remove any particulate or inorganic carbon. Using gloves, the bottles are transferred to a deionized-water dishwasher for 16 minutes to remove any ash. The bottles are then transferred to a drying oven and dried at $60{ }^{\circ} \mathrm{C}$, allowed to cool to room temperature, and then capped for storage. After sample collection, the stoppers are coated with Apiezon grease and secured to the bottles with a positive-pressure closure device (usually stretched black tape or a rubber band with a nylon hose clamp). The $\mathrm{pH}$ samples are collected in 30-mL optical glass cells. The optical glass cells are cleaned by rinsing three times with American Society for Testing and Materials Type II water and are then oven dried.

\section{Collection Equipment}

A peristaltic pump is used to collect discrete seawater samples from the Ocean Carbon System (OCS) location. A 145-millimeter diameter filter barrel and 45-micron Geofilter filter papers are used to pressure filter all samples.

\section{Preservation Reagents}

Each sample is preserved with a small amount of a saturated mercuric chloride $\left(\mathrm{HgCl}_{2}\right)$ solution. Methods published by the Dickson and others (2007) call for a volume of saturated $\mathrm{HgCl}_{2}$ of about 0.02 percent by volume for each sample. This translates to roughly 100 microliters $(\mu \mathrm{L})$ for a $500-\mathrm{mL}$ sample. The $\mathrm{HgCl}_{2}$ is kept in a sealed glass vial. A $100-\mu \mathrm{L}$ pipette is used to draw the $\mathrm{HgCl}_{2}$ from the vial and dispense it into the sample bottles. 


\section{Equipment and Materials List}

- 300 or $500-\mathrm{mL}$ borosilicate BOD bottles with stoppers and positive-pressure closure caps

- 30-mL optical glass cells with Teflon stoppers

- $\mathrm{HgCl}_{2}$ solution (saturated) and syringe

- $\quad 100-\mu \mathrm{L}$ pipette and tips

- Latex (or similar) gloves for protection from chemical exposure

- Label tape and marker

- Apiezon grease

- Peristaltic pump

- Appropriate lengths of peristaltic tubing

\section{Procedure}

1. Upon arriving at the sampling station, lower the calibrated YSI multiparameter meter to the depth of the OCS. Record the temperature, salinity, dissolved oxygen, date, and time in the field notebook.

2. Record the sample bottle numbers, date, and time in the field notebook and on the sample sheet.

3. Connect the peristaltic tubing at the OCS location to the peristaltic pump. Connect the downstream end of tube to the filter barrel. Turn on the peristaltic pump and flush the tube for several minutes.

4. Open the filter barrel valve and purge air from the filter barrel. Close the valve. Inspect the filter barrel and tubing for any remaining air bubbles, and remove bubbles if they are observed.

5. Rinse a 30-mL sample cuvette three times with seawater, then fill the cuvette to overflow and cap without introducing bubbles.

6. Fill the BOD bottle immediately after collection of the $\mathrm{pH}$ sample. Allow the bottle to overflow by at least one bottle volume. Fill from the bottom of the bottle to minimize the introduction of bubbles and contact with air.

7. Pipette $100 \mu \mathrm{L}$ of saturated $\mathrm{HgCl}_{2}$ solution into the bottle while wearing protective gloves.

8. Apply Apiezon grease around the middle of the ground-glass stopper. Insert the stopper in the bottle while applying pressure and twist until the stopper locks into place. Inspect the bottle neck for full coverage of grease around the stopper.

9. Apply electrical tape around the neck and stretch over the top of the stopper to provide a positive-pressure seal.

10. Store the samples in an insulated transport container to minimize rapid temperature changes. 


\section{Reference Cited}

Dickson, A.G., Sabine, C.L., and Christian, J.R., eds., 2007, Guide to best practices for ocean acidification $\mathrm{CO}_{2}$ measurements: North Pacific Marine Science Organization, Special Publication 3, 191 p., accessed April 10, 2018, at https://www.nodc.noaa.gov/ocads/oceans/Handbook_2007/ Guide_all_in_one.pdf. 


\section{Appendix 4. Sample Data and Chain of Custody Forms}

U.S. Geological Survey (USGS) St. Petersburg Coastal and Marine Science Center (SPCMSC) field technicians are responsible for completing the USGS Carbon Sample Data Form and the USGS Carbon Sample Chain of Custody Forms at the time of sample collection. The USGS SPCMSC field technician signs the form upon relinquishing samples to the USGS SPCMSC laboratory technician, the recipient of the samples.

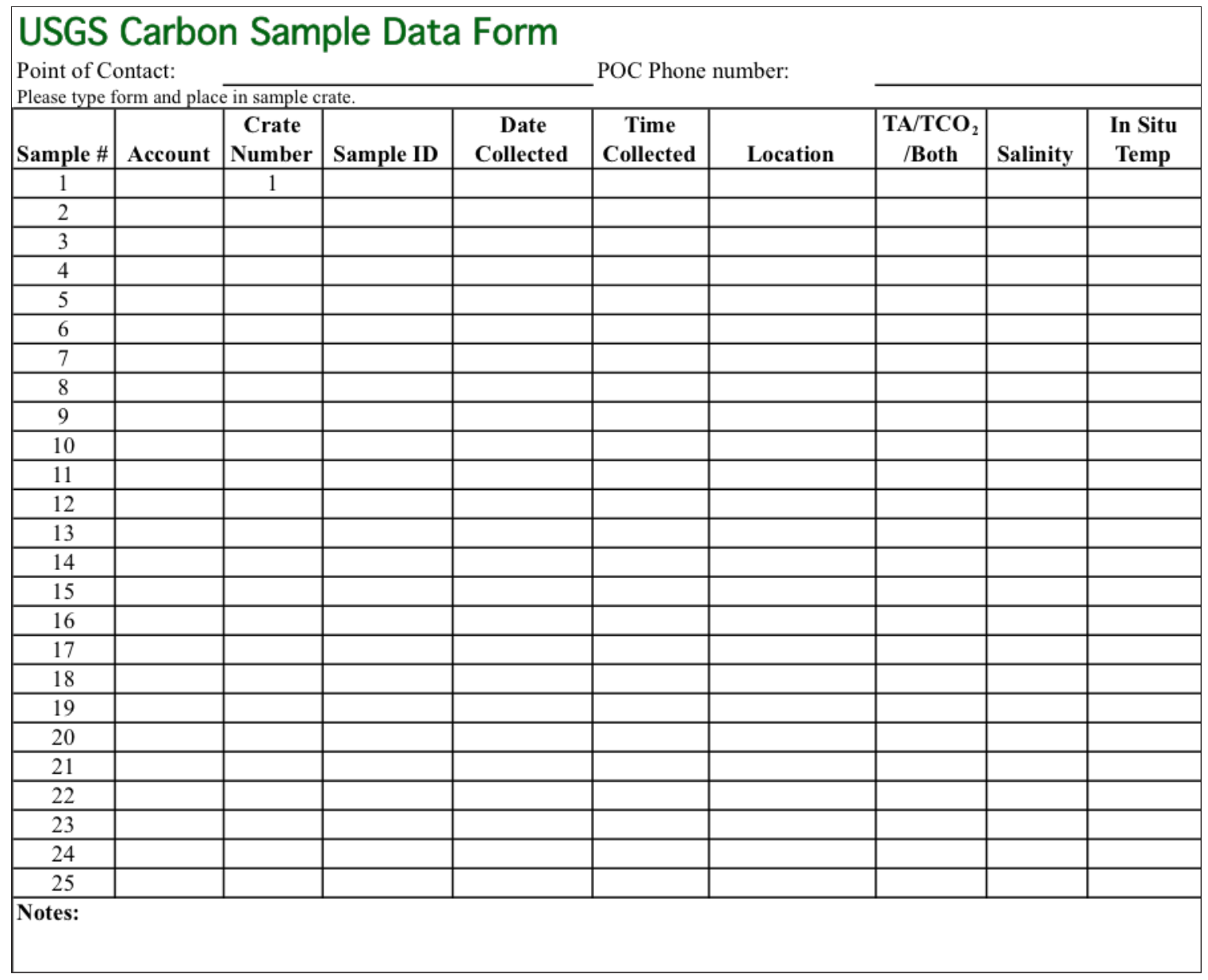




\section{USGS Carbon Sample Chain of Custody Form}

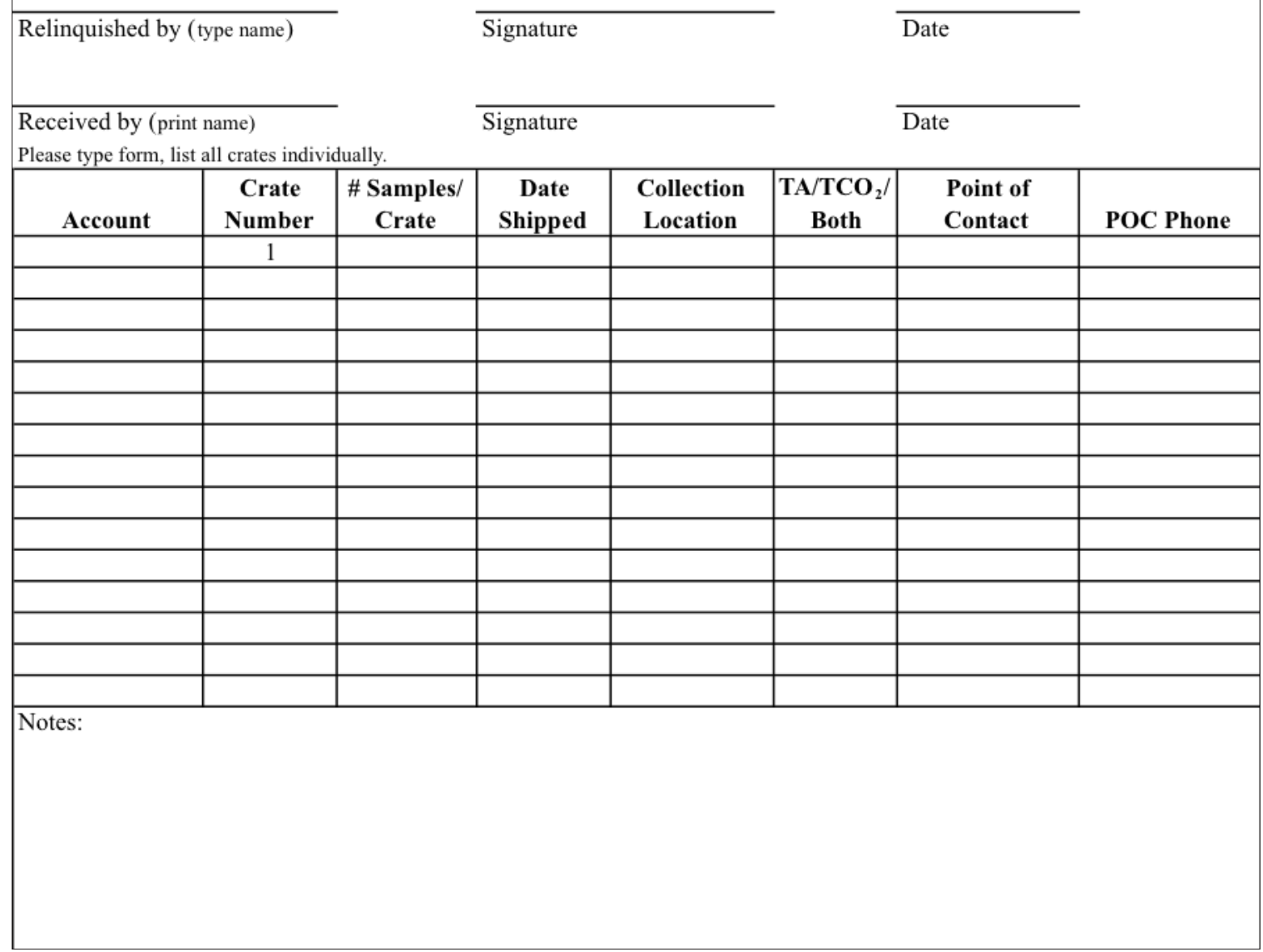




\section{Appendix 5. Standard Operating Procedures for Chemical Analyses}

\section{Spectrophotometric Determination of Total Alkalinity}

The outlined procedures are for the determination of seawater total alkalinity (TA) using a rapid-scan, linear-array spectrophotometer and the methods and equations of Yao and Byrne (1998). The results are expressed as moles per kilogram of seawater. The method has been shown to produce reliable results for salinity values between 20 and 40 and temperature values between 13 degrees Celsius $\left({ }^{\circ} \mathrm{C}\right)$ and $32^{\circ} \mathrm{C}$.

Equipment and Materials List

- Ocean Optics USB2000 (or similar) linear-array spectrophotometer

- Ocean Optics LS-1 light source

- Ocean Optics 2-meter (m) long 400-micrometer $(\mu \mathrm{m})$ diameter optical fibers

- Custom-built polyvinyl chloride (PVC) holder for spectrophotometric cells

- Two Ocean Optics 74-UV collimating lenses

- 6.5-centimeter $(\mathrm{cm})$ x 6.5-cm x 6.0-cm optical quartz glass cell (Hellma Analytics, Inc.)

- 0.2-millimeter (mm)-path-length spectrophotometric cell

- $\quad$ Stir plate and stir bars

- $\quad$ 10-milliliter $(\mathrm{mL})$ syringe

- Teflon needle

- Gas dispersion tube (Ace Glass, Inc.) and water-filled storage flask

- Tank of ultra-high-purity nitrogen gas $\left(\mathrm{N}_{2}\right)$

- Hydrochloric acid ( $\mathrm{HCl}$ ) (approximately 0.1 normal $[N]$ )

- Salinity and temperature probes

- Pipette (0.01 to $0.1 \mathrm{~mL}$ ) and tips

- Approximately $125-\mathrm{mL}$ flask

- Stock solution of approximately 10-millimolar $(\mathrm{m} M)$ bromocresol purple (BCP)

- Analytical balance (resolution of 0.1 milligram [mg])

- Certified reference materials (CRMs) obtained from the Scripps Institution of Oceanography

- $\quad$ Deionized water (Milli-Q)

- Kim-wipes

- Personal computer with OOIBase32 spectrophotometer-operating software

- Laboratory notebook 
Preparation of Bromocresol Purple Stock Solution The chemical formula of bromocresol purple is $\mathrm{C}_{21} \mathrm{H}_{16} \mathrm{Br}_{2} \mathrm{NaO}_{5} \mathrm{~S}$, and the formula weight is 563.20 grams per mole $(\mathrm{g} / \mathrm{mol})$. To make $200 \mathrm{~mL}$ of $10-\mathrm{m} M$ BCP stock solution, dissolve 1.126 grams $(\mathrm{g})$ of BCP in a $200-\mathrm{mL}$ volumetric flask and dilute with deionized water. Place the BCP solution in a glass cell $(0.02-\mathrm{mm}$ path length), or place a drop between two microscope slide covers, and measure the ratio of absorbance of the peaks at 432 nanometers $(\mathrm{nm})$ and $589 \mathrm{~nm}$. Adjust the $\mathrm{pH}$ of the BCP stock solution until the absorbance $(A)$ ratio reaches 0.30 by adding single drops of $1-N$ sodium hydroxide $(\mathrm{NaOH})$ to raise the $\mathrm{pH}$ or $1-N \mathrm{HCl}$ to lower the $\mathrm{pH}\left({ }_{432} A /{ }_{589} A=0.30\right)$. This ratio of absorbance is the target R-value of the dye, and the ideal value of the titration's endpoint in determining TA.

\section{Preparation of Hydrochloric Acid}

To make 1 liter (L) of $0.1-N \mathrm{HCl}$ from a $12.1-N$ stock solution, use the following equation: $\mathrm{C}_{1} \mathrm{~V}_{1}=\mathrm{C}_{2} \mathrm{~V}_{2}$

whereby $\mathrm{C}_{1}$ is the concentration of the initial stock of acid and $\mathrm{C}_{2}$ is the desired or final concentration of acid. $\mathrm{V}_{1}$ is the volume of acid at concentration $\mathrm{C}_{1}$ that should be diluted to obtain the final volume, $\mathrm{V}_{2}$, of acid solution.

\section{Running Samples or Certified Reference Materials}

1. Turn on the spectrophotometer lamp and let it warm up for 20 minutes while configuring the OOIBase 32 spectrophotometer software.

2. Make sure the fiber optic connectors are secure at the lamp, sample holders, and spectrophotometer.

3. Turn on the stirrer to slightly less than full speed.

4. Verify under the "Time Acquisition" tab in the OOIBase 32 program that the spectrophotometer collects data in absorbance wavelengths characteristic of BCP at $589 \mathrm{~nm}$ and 432 $\mathrm{nm}$ as well as a baseline wavelength of $750 \mathrm{~nm}$.

5. Enter spectrum mode by clicking the " $\mathrm{S}$ " button and adjust the "Integration Time" and (or) "Spectra to Average" so that the spectrum intensity is between 3,000 and 3,500 counts.

6. With the light path completely blocked, record a "Global Dark" by clicking the black light bulb button. Next, take a "light" reference with an unobstructed light path by clicking the yellow light bulb button. Make sure your spectrophotometer is now set in absorbance mode by clicking the " $\mathrm{A}$ " button, then adjust the scale to observe absorbed light in the 400 to $800 \mathrm{~nm}$ range (x-axis) in an absorbance range of 0 to 1 absorbance units (y-axis).

7. Turn on the $\mathrm{N}_{2}$ gas and adjust the pressure regulator valve to get a steady stream of small bubbles in the approximately $125-\mathrm{mL}$ flask.

8. Thoroughly mix the contents of the sample bottle, remove the stopper, and use a Kimwipe to remove as much grease as possible from the neck of the sample bottle. 
9. Pour 100 to $101 \mathrm{~mL}$ of sample into the 125 -mL flask, then place the flask on the analytical balance and zero.

10. Carefully pour the sample into the clean quartz glass cell containing the stir bar and set to stir at medium speed. Reweigh the now empty $125-\mathrm{mL}$ flask and record the value as the mass of seawater. Place the cell in the spectrophotometer cell holder.

11. Before storing a reference (blank by clicking the yellow light bulb button in the OOIBase 32 operating software), use a pipette to add an appropriate amount of BCP stock solution to make the final solution approximately 10 -micromolar BCP. For example, for a $100-\mathrm{mL}$ sample and a stock solution of approximately $10-\mathrm{mM} \mathrm{BCP}$, add approximately $0.100 \mathrm{~mL}$ of BCP stock solution to the sample.

12. Weigh a $10-\mathrm{mL}$ syringe fitted with a Teflon needle and filled with approximately $0.1 \mathrm{~N}$ $\mathrm{HCl}$. Record the syringe weight in laboratory notebook.

13. Initiate the software program by clicking on the clock button and then the green arrow button. Add approximately $2 \mathrm{~mL}$ of HCL from the syringe and allow the spectrum to stabilize.

14. The goal is to titrate with the acid until the "combo" (also referred to as the calculated $\mathrm{R}$-value) reaches approximately 0.080 ( $\mathrm{pH}$ of approximately 4.2). Begin continuous monitoring of the appropriate wavelengths, paying close attention to the "combo." The color of the solution will start as a deep purple and will begin to turn yellow as the $\mathrm{pH}$ decreases. When the "combo" nears 0.300 , slowly add HCL one half drop at a time. The final "combo" before purging with $\mathrm{N}_{2}$ will fluctuate approximately 0.001 units.

15. After reaching the target "combo" of 0.080 , purge the solution with $\mathrm{N}_{2}$ using the gas dispersion tube for at least 5 minutes or until the "combo" stabilizes. Store the gas dispersion tube in deionized water between uses to prevent dehydration of the glass frit. Verify that the frit that is expelling $\mathrm{N}_{2}$ does not interfere with the light path. Gas flow should not splash fluid out of the cell. Once the peak has stabilized, remove the gas frit, return it to the storage flask, and turn off the gas. Wait for the "combo" to stabilize without the gas flow. The goal is to achieve a "combo" of 0.300 ( $\mathrm{pH}$ of approximately 4.8) when using BCP. If the "combo" is greater than 0.300 after stabilization, add very small amounts of acid and repeat the steps to purge the acid with $\mathrm{N}_{2}$.

16. After the titration is complete, remove the gas dispersion tube and click the pause button once the "combo" stabilizes. Measure and record the temperature of the titrated sample. Record the final "combo" and final absorbance measurements at each wavelength ${ }_{589} A$, $\left.{ }_{432} A,{ }_{750} A\right)$ and remove the baseline offset $\left({ }_{589} A-{ }_{750} A /{ }_{432} A-{ }_{750} A\right)$. The baseline offset is the absorbance ratio $\mathrm{R}(\mathrm{T})$ at the measurement temperature $(\mathrm{T})$.

17. Weigh the acid syringe. Calculate (by difference) and record the weight of added acid $\left(\mathrm{M}_{\mathrm{A}}\right)$. Calculate the TA of the sample using the equations from Yao and Byrne (1998). 


\section{Coulometric Determination of Total Dissolved Inorganic Carbon in Seawater}

This procedure is for the determination of total dissolved inorganic carbon (DIC) in seawater using coulometry and the methods and equations of Dickson and others (2007). The results are expressed as moles per kilogram of seawater. The method has been shown to produce reliable results of in situ total dissolved carbon concentrations in a range of 1,800 to 4,300 micromoles per kilogram $(\mu \mathrm{mol} / \mathrm{kg})$.

The total DIC content of seawater is defined as

$$
\mathrm{C}_{\mathrm{T}}=\left[\mathrm{CO}_{2}{ }^{*}\right]\left[\mathrm{HCO}_{3}^{-}\right]\left[\mathrm{CO}_{3}^{2-}\right] \text {. }
$$

Brackets represent total concentrations of these constituents in solution (in moles per kilogram $(\mathrm{mol} / \mathrm{kg})$, and $\left[\mathrm{CO}_{2}{ }^{*}\right]$ represents the total concentration of all un-ionized carbon dioxide, whether present as carbonic acid $\left(\mathrm{H}_{2} \mathrm{CO}_{3}\right)$ or dissolved carbon dioxide $\left(\mathrm{CO}_{2}\right)$. Additional information can be found in Dickson and others (2007).

\section{Equipment and Materials List}

- $\mathrm{CO}_{2}$ Coulometer (UIC, Inc. Model 5014 or later)

- Acidification Module (UIC, Inc. Model CM5130)

- Carbon Cathode Solution (UIC, Inc.)

- Carbon Anode Solution (UIC, Inc.)

- Potassium iodide salt (UIC, Inc.)

- Potassium Hydroxide 45 percent by weight (Fisher Scientific)

- Phosphoric Acid 8.5 percent (diluted 10:1 from 85-percent Phosphoric Acid)

- Tank of ultra-high-purity $\mathrm{N}_{2}$

- Compressed-gas tank regulator (minimum pressure of 15 pounds per square inch [psi] and maximum pressure of $20 \mathrm{psi}$ )

- Teflon-coated stir bar

- Cell assembly (UIC, Inc.)

- Hot plate

- 60-mL vials (UIC, Inc.)

- 60-mL syringes (Luer-Lok)

- $\quad 18 \mathrm{G}$ (gauge) $1 \frac{1}{2}$ inch sterile needles

- Red rubber septums (UIC, Inc.)

- CRM obtained from the Scripps Institution of Oceanography

- Analytical balance (resolution of $0.1 \mathrm{mg}$ )

- Gas dispersion tube (Ace Glass, Inc.)

- 24-pin printer (Panasonic KXP2130 or later model)

- Timer

- Laboratory notebook 
- Two-port rubber bottle stopper and extraction tube fitted with a two-way Luer-Lok fitting

- Small Kimwipes

- Deionized water (Milli-Q)

- 1,000-mL waste beaker

Instrument Preparation

1. Turn on the coulometer at least 1 hour before the projected analysis start time.

2. Assemble the cell according to UIC, Inc. cell assembly instructions.

3. Once assembled, connect the cell to the coulometer and acidification module using color-coded gas lines and electrode wires from UIC, Inc.

4. Program the instrument using the following system parameters:

- $\mathrm{CO}_{2}$

- Weight

- Difference- 0.2

- Factor - use factory setting

- Number of readings - use factory setting

- Interval- 0.5 minutes

- Timing Method - Coulometer Endpoint

- Sampling-Manual

- Printing-Normal

- Write to Disk-No

5. Turn on the acidification module and $\mathrm{N}_{2}$ tank making sure the gas tank regulator is set between 15 and 20 psi.

6. Set the acidification module airflow to approximately $100 \mathrm{~mL}$ per minute and monitor for consistent flow at that level.

7. Enter "Cell Setup" mode on the coulometer and adjust the cell position to get the highest cell counts within the value range of 2,700 to 4,000 and be stable within 10 digits for 2 to 10 minutes. Operating outside of this value range will compromise data. See the UIC, Inc. operation manual for further details.

8. Once stable, purge any bubbles from the acid line by pumping $10 \mathrm{~mL}$ of phosphoric acid into the sample vial. Replace the vial after 3 minutes. Wait 3 minutes after replacing the vial before initializing cell titration.

9. Turn on the cell current according to UIC, Inc. operation manual instructions. The cell will begin titrating down to a value of 29.5 percent transmission.

10. At this point, the instrument should have been on for 2 to 3 hours. Allow the cell to stabilize for an additional 1 to 2 hours. This allows the internal boards to warm up sufficiently for analysis. 


\section{Running Blanks}

1. Once the cell has stabilized for at least 1 hour, run a number of blanks (at least three) according to the UIC, Inc. operation manual instructions to assess stability and gas flow.

2. Each run will take 2 to 3.5 minutes, and the results should be under 2 micrograms.

\section{Running Samples or Certified Reference Materials}

A CRM can be used for both DIC and TA analysis; however, DIC must be analyzed as soon as the CRM bottle is opened due to immediate gas exchange. The procedure for running samples is the same as for running CRMs.

1. Prior to opening the CRM bottle, record the batch and bottle numbers in the laboratory notebook.

2. Open the bottle and wipe grease off the bottle neck.

3. Plug the bottle with a two-port stopper with extraction tube.

4. Remove the needle from a 60 -mL syringe and attach it to the stopper tube via the Luer-Lok fitting.

5. Draw $10 \mathrm{~mL}$ of CRM into the syringe, remove the syringe from the tube ensuring ambient air does not return to the CRM bottle, attach the needle, and discard CRM through the needle tip into a waste beaker. Repeat this step.

6. Load the syringe with $15 \mathrm{~mL}$ of CRM and close the Luer-Lok without disconnecting it from the tube.

7. Expel all air and air bubbles from the syringe. Bubbles attached to the syringe's inner wall and stopper can be dislodged by tapping the syringe on the rim of the waste beaker.

8. Once all air bubbles have been expelled, push out as much CRM as possible. Open the Luer-Lok to the CRM bottle and load the syringe slowly, taking care not to generate air bubbles in the process. If air bubbles are generated, they should be expelled and the previous step repeated until $65 \mathrm{~mL}$ of CRM is loaded into the syringe with no bubbles.

9. Disconnect the syringe from the Luer-Lok and attach the needle. Expel $5 \mathrm{~mL}$ of CRM to remove any air bubbles in the Luer-Lok fitting and syringe.

10. Repeat the CRM extraction with an additional syringe for complete CRM analysis.

11. Place the syringe with CRM on a balance and tare.

12. On the coulometer, enter the sample name and 20.0 for weight (this is the approximate weight in grams).

13. When you are ready to inject the sample for analysis, initiate the coulometer to begin the same moment you begin to inject $20 \mathrm{~mL}$ of sample through the rubber septum sample port on the acidification module. 
14. Sample injection must be done slowly to prevent backfill into the syringe, carrier gas line and acid line. When injecting the sample, ensure that none of the sample is left on the inner wall of the injection column. The injection pressure and timing must be replicated for each injection to ensure analysis consistency throughout entire operation.

15. After the needle is removed, pump $10 \mathrm{~mL}$ of phosphoric acid to prevent backfill into the carrier gas line and to rinse sample off the inner wall of the injection column.

16. Verify that the septum is not leaking by applying a droplet of deionized water over the injection port on the septum.

17. Place the syringe back on the balance and record the weight.

18. Sample analysis will take about 5 minutes.

19. Record the coulometer reading for $\mathrm{CO}_{2}$ in parts per million (ppm) once the analysis is complete.

20. Change out the sample vial for a clean vial and let it purge for 3 minutes. Rinse out the used sample vial three times with deionized water.

21. Calculate the total DIC of the sample using the following equations. Additional information can be found in Dickson and others (2007).
A. [DIC] ppm * (Estimated Weight $(\mathrm{g}) /$ Sample Weight $(\mathrm{g}))=$ Corrected [DIC] ppm
B. Corrected [DIC] ppm * (1000g per kg seawater / $44.009 \mathrm{~g} \mathrm{CO}_{2}$ per mol)

\section{Spectrophotometric $\mathrm{pH}$ Analysis}

This procedure describes a method for the spectrophotometric determination of the $\mathrm{pH}$ of seawater on the total $\mathrm{pH}$ scale using the sulfonephthalein indicator thymol blue and the methods and equations of Zhang and Byrne (1996). Additional information on spectrophotometric determination of the $\mathrm{pH}$ of seawater can be found in Dickson and others (2007). These measurements can be performed in the field while working on small vessels or in a laboratory setting.

\section{Equipment and Materials List}

- Ocean Optics USB2000 linear-array spectrophotometer

- Ocean Optics LS-1 light source

- Ocean Optics 2-m long 400- $\mu$ m-diameter optical fibers

- Ocean Optics CUV-UV-10 cuvette holder

- 10-cm-path-length spectrophotometric cells

- 0.2-mm-path-length spectrophotometric cells

- Salinity and temperature probe

- Pipette (0.01 mL to $0.1 \mathrm{~mL})$ and tips

- Pipette tips $(0.1 \mathrm{~mL}$ to $1.0 \mathrm{~mL})$ 
- Stock solution of thymol blue $(2 \mathrm{mM})$

- Personal computer with OOIBase32 spectrophotometer-operating software

- Deionized water

- Laboratory notebook

\section{Preparation of Thymol Blue}

The chemical formula of thymol blue is $\mathrm{C}_{27} \mathrm{H}_{30} \mathrm{O}_{5} \mathrm{~S}$, and the formula weight is $466.59 \mathrm{~g} /$ mol. To make $200 \mathrm{~mL}$ of a $2-\mathrm{m} M$ thymol blue solution, dissolve $0.187 \mathrm{~g}$ of thymol blue in a $200-\mathrm{mL}$ volumetric flask and dilute with deionized water. Mix until the solution is homogenous and cap the flask using a lid that is not permeable to gas exchange. Place the thymol blue solution in a short path-length spectrophotometric cell (0.02-mm path length), or place a drop between two microscope slide covers. Use the spectrophotometer to obtain the ratio of absorbance of the peaks at $435 \mathrm{~nm}$ and $596 \mathrm{~nm}$. Adjust the absorbance ratio of the stock solution until the absorbance ratio reaches 0.82 by adding single drops of $1-\mathrm{N} \mathrm{NaOH}$ or $1-\mathrm{N} \mathrm{HCl}$ to raise the $\mathrm{pH}$ $\left({ }_{435} A /{ }_{596} A=0.82\right)$. This ratio is the target $\mathrm{R}$-value of the dye.

\section{Sample Collection}

1. Thoroughly flush the sample collection tube with seawater prior to sample collection. Rinse the spectrophotometric cell end caps, then rinse the cell three times by filling to overflow from one end of the cell with sample water.

3. Fill the cell from one open end to allow all air bubbles to escape from the opposite end. Cap both ends, ensuring there are no bubbles in the cell.

4. Record the temperature and salinity at the time of collection.

\section{Sample Analysis}

1. Turn on the spectrophotometer lamp and let it warm up for 20 minutes while configuring the OOIBase 32 spectrophotometer software.

2. Make sure the fiber optic connectors are secure at the lamp, cuvette holders, and spectrophotometer.

3. Verify under the "Time Acquisition" tab in the OOIBase 32 program that the spectrophotometer collects data in absorbance wavelengths characteristic of thymol blue at $596 \mathrm{~nm}$ and $435 \mathrm{~nm}$ as well as a baseline wavelength of $750 \mathrm{~nm}$.

4. Enter spectrum mode by clicking the " $\mathrm{S}$ " button and adjust "Integration Time" and (or) "Spectra to Average" until the spectrum intensity is between 3,000 and 3,500 counts.

5. With the light path completely blocked, record a "Global Dark" by clicking the black light bulb button. Next, take a "light" reference with an unobstructed light path by clicking the yellow light bulb button. Make sure your spectrophotometer is now set in absorbance mode by clicking the " $\mathrm{A}$ " button, then adjust the scale to observe absorbed light in the 400 $\mathrm{nm}$ to $800 \mathrm{~nm}$ range (x-axis) in an absorbance range of 0 to 1 absorbance units (y-axis). 
6. When ready for analysis, clean and dry the exterior of the cell, place it in the cuvette holder, and store a reference (blank) measurement. Remove one of the cell caps, add approximately $0.04 \mathrm{~mL}$ of concentrated thymol blue solution (approximately $2 \mathrm{mM}$ ) to the sample, replace the cap, and invert the cell several times to mix the seawater and dye.

7. Return the cell to the cuvette holder and measure the absorbance at the three designated wavelengths: a non-absorbing wavelength $(750 \mathrm{~nm})$ and the wavelengths corresponding to the absorption maxima of the base $\left(\mathrm{I}^{2-}\right)$ and acid $\left(\mathrm{HI}^{-}\right)$forms of the thymol blue solution at $596 \mathrm{~nm}$ and $435 \mathrm{~nm}$, respectively. Cells should be positioned in the cell holder to maintain consistent alignment between the baseline and indicator absorbance measurements.

8. The absorbance measured at a non-absorbing wavelength of $750 \mathrm{~nm}$ is used to monitor and correct for any baseline shift due to error in repositioning the cell or instrumental shifts. This method assumes that the magnitude of any observed baseline shift is identical across the visible spectrum. To correct for baseline shift, subtract the non-absorbing wavelength from each absorbance maxima $\left({ }_{596} A\right.$ to $\left.A_{750}\right)$ and $\left({ }_{435} A\right.$ to $\left.A_{750}\right)$ to obtain the final corrected absorbance value at each wavelength. These final absorbance values, cor-

rected for observed baseline shifts, are used to calculate $\mathrm{R}\left({ }_{435} A /{ }_{596} A\right)$, the absorbance ratio that describes the extent of protonation of the dye.

9. After the absorbance measurements are recorded, immediately measure the temperature of the sample and record this value as the analytical temperature.

10. $\mathrm{pH}$ is calculated at the analytical temperature and then corrected to in situ temperature using CO2SYS.

11. Finally, it is important to analyze $\mathrm{pH}$ samples as soon as possible. Temperature fluctuations from the time samples are collected to the time of analysis can create significant errors. This method is designed for analysis of samples collected during field deployments on small vessels where a thermostat bath is not available. Note that the system described here can be used with a temperature-control system attached to the Ocean Optics CUVUV-10 cuvette holder.

\section{References Cited}

Dickson, A.G., Sabine, C.L., and Christian, J.R., eds., 2007, Guide to best practices for ocean acidification $\mathrm{CO}_{2}$ measurements: North Pacific Marine Science Organization, Special Publication 3, 191 p., accessed April 10, 2018, at https:/www.nodc.noaa.gov/ocads/oceans/Handbook_2007/ Guide_all_in_one.pdf.

Yao, W., and Byrne, R.H., 1998, Simplified seawater alkalinity analysis-Use of linear array spectrometers: Deep-Sea Research Part 1-Oceanographic Research Papers, v. 45, no. 8, p. 13831392. [Also available at https://doi.org/10.1016/S0967-0637(98)00018-1.] 
ㄱ.

高

음.

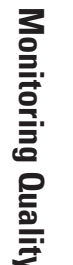

